\title{
Brock Center for Agricultural Communication Program of Work
}

Created Fall 2013 by Megan Silcott, Director

Brock Center for Agricultural Communication 


\section{Contents}

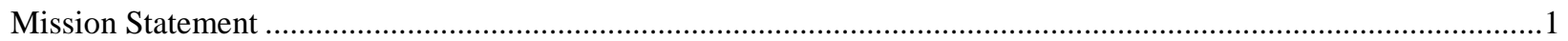

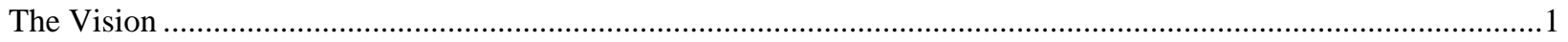

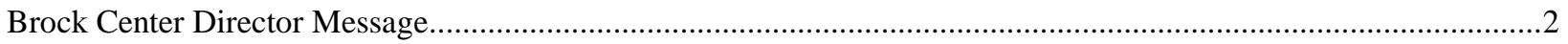

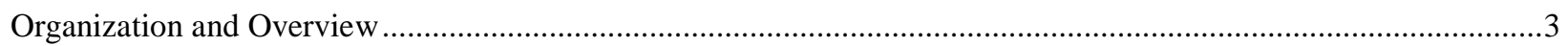

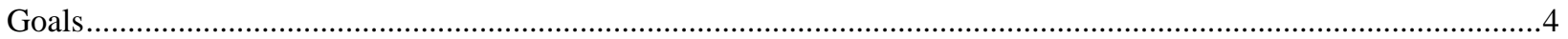

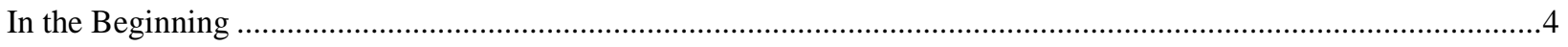

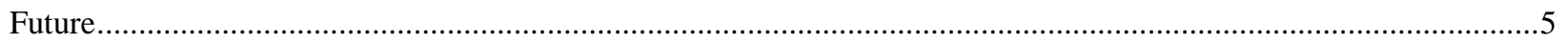

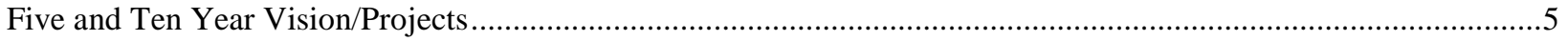

Brock Center Chart of Responsibilities and Job Descriptions .......................................................................6

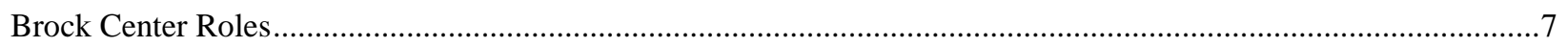

Brock Center Associate Employment Expectations and Contract ...........................................................8

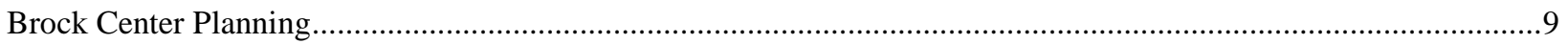

Equipment Replacement, Check Out Procedures, Inventory List................................................................11

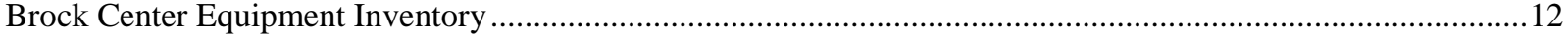

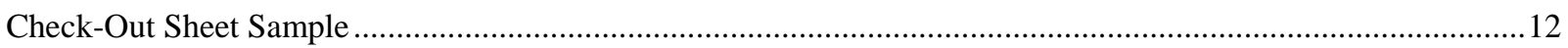

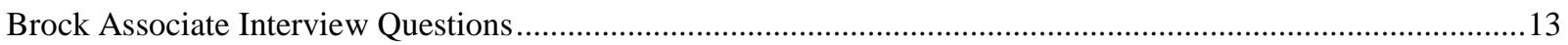

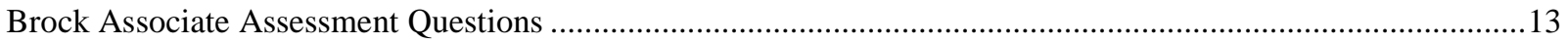

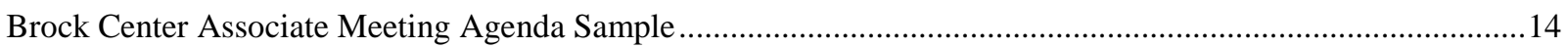

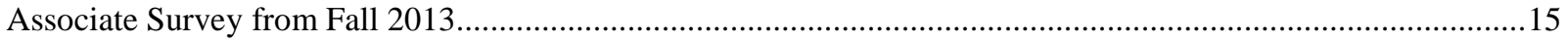

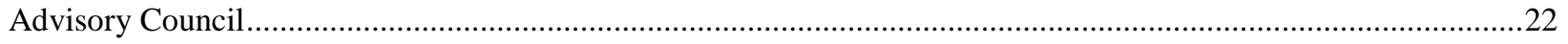

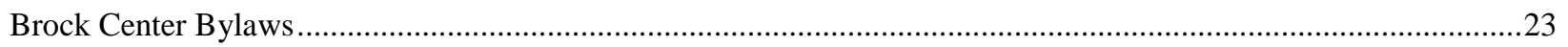

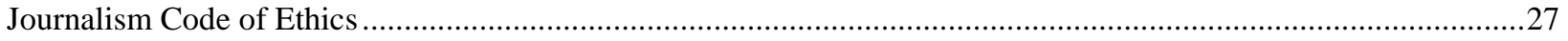

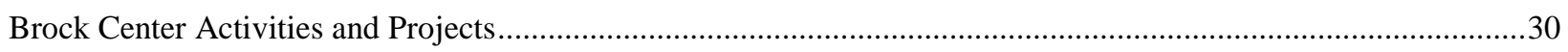

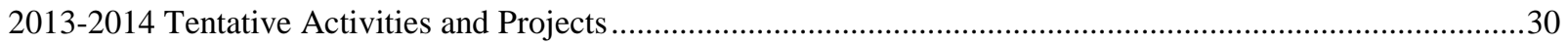

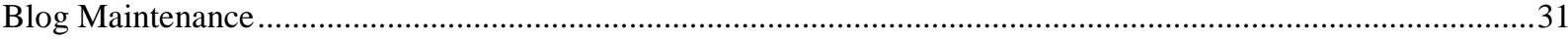

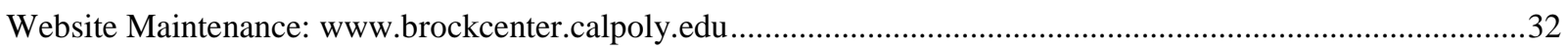

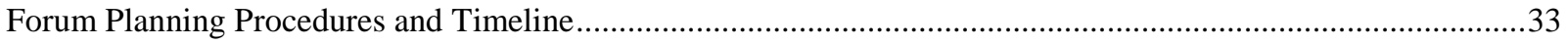

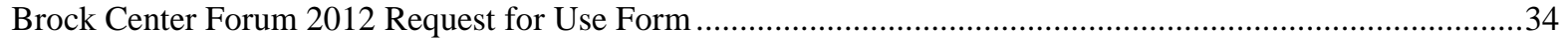

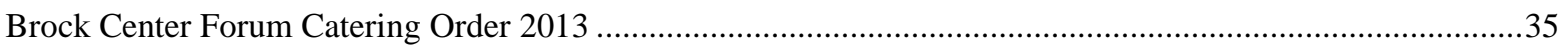

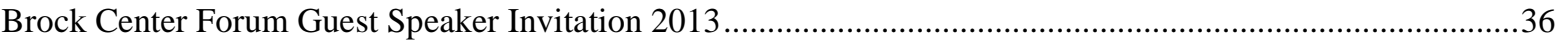

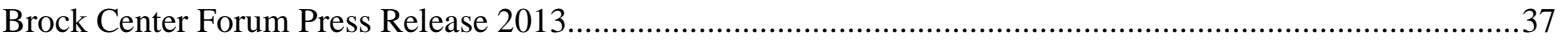

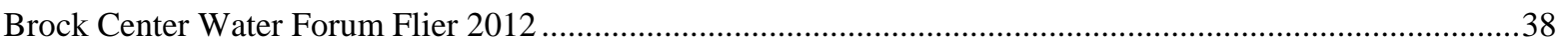

Brock Center California Ag Issues and Sustainability Forum Flier 2013..................................................39

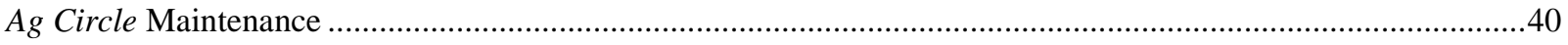

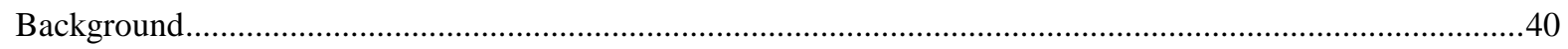

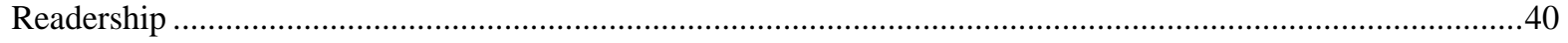

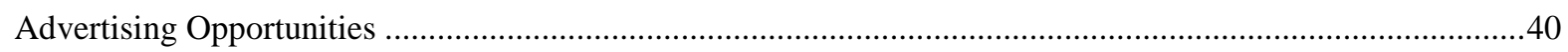


Steps to Ag Circle Production......................................................................................................................4

Printing Expenses for Ag Circle with PRP Co. in San Luis Obispo, CA. ......................................................

Writer's Tips Sheet from Winter 2013 .........................................................................................................42

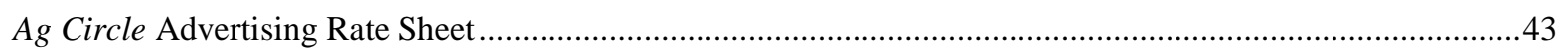

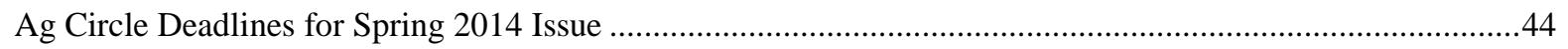

Ag Circle Critique from the winning Spring 2012 Issue ....................................................................................45

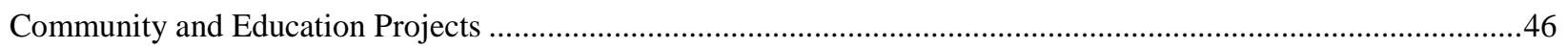

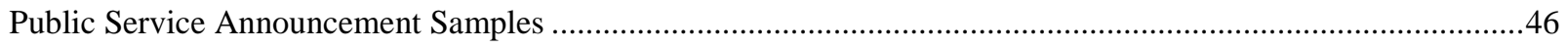

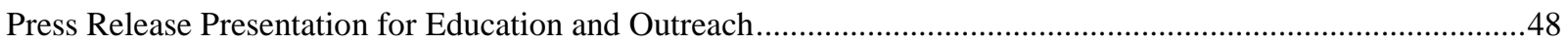

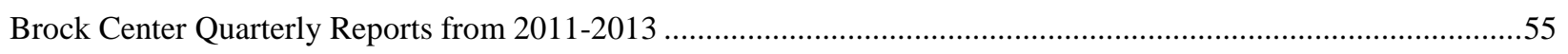

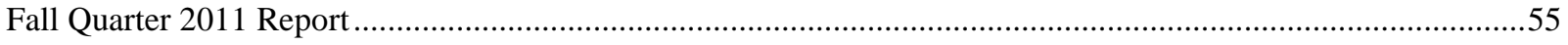

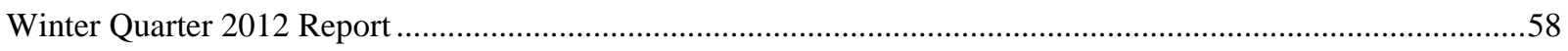

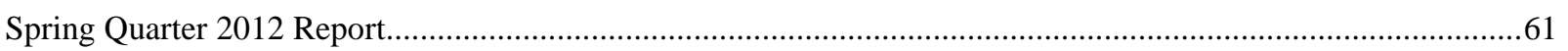

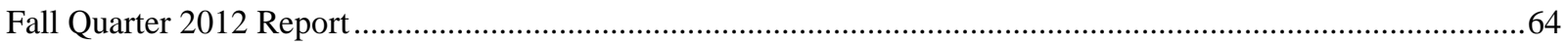

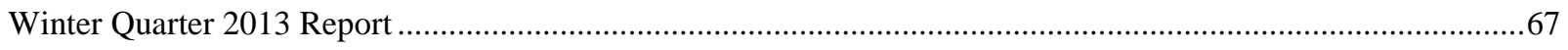

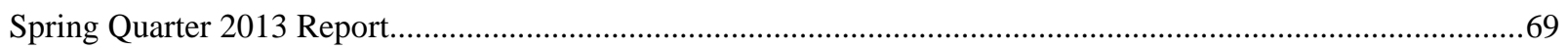

Brock Center Director and Staff History ……………........................................................................................ 


\section{Mission Statement}

The mission of the Brock Center for Agricultural Communication is to create a bridge of communication between the agricultural industry, the media and the public.

\section{The Vision}

"Agriculture is the biggest and best industry in the United States. It has set standards of efficiency and high production that have done more than anything else to assure our high standard of living. Its very efficiency, however, has drastically reduced the actual numbers of those required to produce our food. As political power is measured by voting strength, the lessened numbers have greatly reduced agriculture's clout. Furthermore, it has become the most misunderstood industry in the country and the constant target for derogatory media comment. Why not try to do something to improve agriculture's badly battered image with the balance of society? No substantial contribution had ever been made for this purpose and we saw an opportunity to, in our small way, do more good than through any other course we could imagine.”

\section{- Jim Brock}

Figure 1: Brock Center Sign in Building 10-234

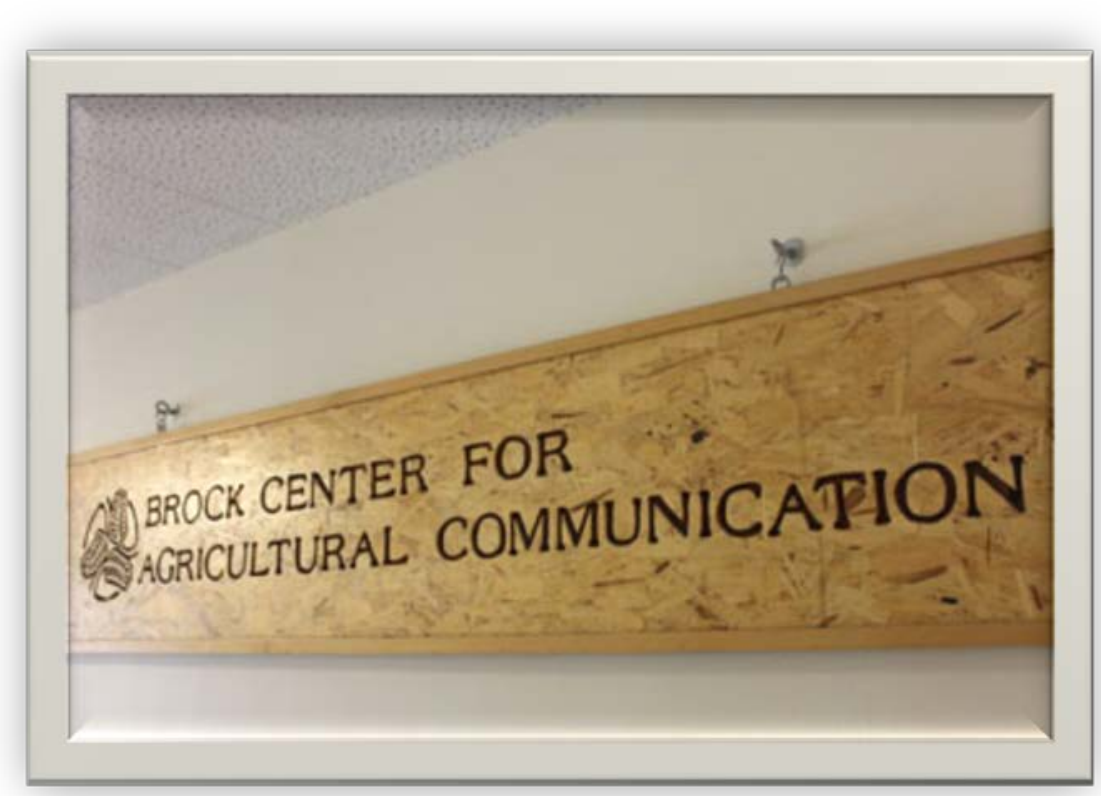




\section{Brock Center Director Message}

The Brock Center is an extension to students' curriculum. Beyond campus, the Brock Center provides outreach through workshops and forums for the community to gain knowledge and experience agriculture issues and trends. The Center is designed to serve as a connection between consumers and the agriculture industry feeding, clothing and housing them. Defining the channels of communication used by the Brock Center to accomplish its' mission is both challenging and rewarding. New means of social media, hard copy, design and advertising keep the Center searching for trending ways to provide agriculture education. The Center meets these challenges by adding to its knowledge base, equipment and technology. Together with the Journalism Department and Agricultural Education and Communication Department, the Brock Center will thrive, improve and grow its’ capabilities and output. 


\section{Organization and Overview}

Director: Megan Silcott, 2011-present

Supervised by Dean Doug Epperson, College of Liberal Arts and

Interim Dean Andrew Thulin, College of Agriculture, Food and Environmental Sciences

Directly Supervised by Dr. Bill Kellogg, Department Head for Agricultural Education and

Communication

Supported by Mary Glick, Department Head for Journalism

Current Brock Staff:

Editor-in-Chief: Taylor Pires, DSCI

Associate: Amanda Meneses, AGC

Associate: Kenna Lewis, AGC

Associate: Jordan Dunn, AGC

Each quarter, the paid Brock Center staff develops a list of potential feature and technical stories to focus on. The team then delegates the stories and directs volunteer writers from any department on campus with interviewing, photography and writing. The staff edits story submissions and uses those to develop the Ag Circle magazine and the Brock Center blog. The end result produces three magazines and nearly 100 blog posts each academic year. 


\section{Goals}

The Brock Center for Agricultural Communication has aggressively pursued the following goals to heighten public awareness and understanding of agricultural issues:

- Locate and attract prospective undergraduate students who demonstrate aptitude for communication and have an abiding concern for agriculture.

- Assist the university's Colleges of Agriculture, Food and Environmental Sciences, and Liberal Arts in preparing these students to be effective professional communicators, through learn-by-doing opportunities.

- Serve as a resource and vehicle for the continuing education of those in a position to promote the understanding of agriculture.

- Promote the professional development of university faculty through teaching, research and service to agriculture communication.

- Develop and maintain a website as a resource of information on agricultural issues to serve students, faculty, media professionals, agriculturists and the public.

\section{In the Beginning}

Jim Brock was a Cal Poly agriculture alumnus and a former leader in the western vegetable industry. His desire to enhance the image of the agriculture industry has led to the expansion of undergraduate education opportunities for Cal Poly students interested in agricultural communication.

The Brock Center for Agricultural communication was established through the generosity of Jim Brock and his wife

Figure 2: Jim and Martha Brock

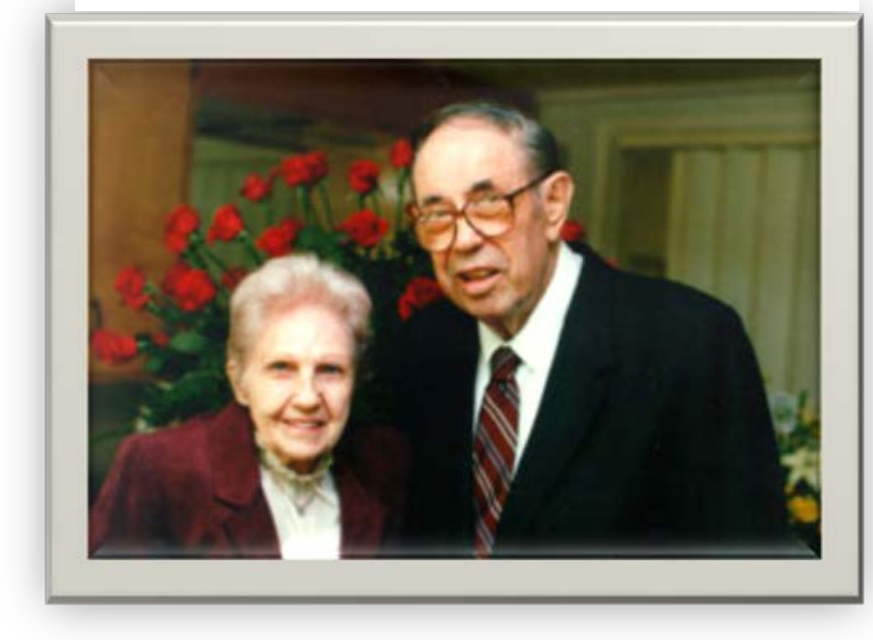
Martha. Their lifelong commitment to agriculture will be continued through the center. It is one answer to the expressed need of the agriculture industry for help with efforts to improve communication with the public.

The center's operations are funded by resources from a $\$ 1.5$ million trust established by the Brocks to help make their dream a reality. 


\section{Future}

The Brocks' investment in the future of agricultural communication is a sound one. Cal Poly has been in the business of preparing agricultural journalists for some 80 years. It remains the only such program in California and one of the premier undergraduate programs in the United States.

A recent study found substantial need for more agricultural communicators, now and in the future, throughout California and the United States. With the help of the Brock Center, Cal Poly has successfully produced and placed many leaders in the agricultural communication profession.

Cal Poly and the Brock Center are dedicated to producing professional agricultural communicators who make a positive impact on our nation's most vital industry.

Five and Ten Year Vision/Projects

The Brock Center's future is certainly bright. More and more talented and driven young people continue to rise through the ranks at the Brock Center. With guidance, there are few limits to what the Center can accomplish.

In the next five years, the Brock Center will continue to utilize the support of the Journalism Department and expand its projects to incorporate more Journalism students and faculty. New equipment will be added to the Center including more video cameras of higher quality, more digital audio equipment, updated computer systems and additional online accounts to improve learning and research projects. The Ag Circle magazine will bring home more accolades to reflect its quality and improvements. Community forums will continue to be offered and income is to be gained from offering professional development workshops.

In the next ten years, the Brock Center will be well known across the nation as an outlet for agricultural communications, research and having outstanding students ready for the workplace. An additional space will be acquired for social media and video production while the current location will remain the writing center. Within ten years, the University will have come to depend and utilize the Brock Center as a communication tool that the industry comes to for information, education and top notch publications and video work. 


\section{Brock Center Chart of Responsibilities and Job Descriptions}

\begin{tabular}{|l|l|l|l|}
\hline Position/Task & Editor-in-Chief & Brock Associates & Brock Director \\
\hline Deliver Magazines to Readers & $\mathrm{X}$ & $(\mathrm{X})$ & $\mathrm{X}$ \\
\hline Submit Magazine to Printer & $\mathrm{X}$ & & $(\mathrm{X})$ \\
\hline Finalize Magazine for Online Publication & $(\mathrm{X})$ & $\mathrm{X}$ & $\mathrm{X}$ \\
\hline Finalize Magazine Design & $(\mathrm{X})$ & & \\
\hline Design Magazine Layout & $(\mathrm{X})$ & $\mathrm{X}$ & $\mathrm{X}$ \\
\hline Coordinate Magazine Advertisers & & $(\mathrm{X})$ & \\
\hline Adjust Photos to RGB & $\mathrm{X}$ & $(\mathrm{X})$ & \\
\hline Adjust Text to Black & $\mathrm{X}$ & $\mathrm{X})$ & \\
\hline Develop and Write Articles/Stories & $\mathrm{X}$ & $(\mathrm{X})$ & $\mathrm{X}$ \\
\hline Edit Stories & $(\mathrm{X})$ & $\mathrm{X}$ & $\mathrm{X}$ \\
\hline Delegate/Guide Student Writers & $\mathrm{X}$ & $\mathrm{X})$ & \\
\hline Secure Photos for Articles & $\mathrm{X}$ & $(\mathrm{X})$ & $\mathrm{X}$ \\
\hline Develop and Share Due Dates & $(\mathrm{X})$ & $\mathrm{X}$ & $(\mathrm{X})$ \\
\hline Maintain Website & & $\mathrm{X}$ & \\
\hline Maintain Social Media & $\mathrm{X}$ & $\mathrm{X})$ & $\mathrm{X}$ \\
\hline Maintain and Plan Blog & $\mathrm{X}$ & $(\mathrm{X})$ & $(\mathrm{X})$ \\
\hline Develop Quarterly Reports & & & $(\mathrm{X})$ \\
\hline Develop and Host Community Forums & $\mathrm{X}$ & $\mathrm{X}$ & $\mathrm{X}$ \\
\hline Attend and Participate in Weekly Meetings & $\mathrm{X}$ & $(\mathrm{X})$ & \\
\hline $\begin{array}{l}\text { Maintain Cleanliness and Organization of } \\
\text { Brock Center Office }\end{array}$ & $\mathrm{X}$ & $(\mathrm{X})$ & \\
\hline Update Hallway Displays & $\mathrm{X}$ & $\mathrm{X})$ & $(\mathrm{X})$ \\
\hline Maintain Equipment Checkout Procedures & $\mathrm{X}$ & $\mathrm{X}$ & $(\mathrm{X})$ \\
\hline $\begin{array}{l}\text { Produce Short Videos Highlighting } \\
\text { Mission Statement }\end{array}$ & $\mathrm{X}$ & $\mathrm{X}$ & $\mathrm{X}$ \\
\hline Develop and Host Photography Workshops & $\mathrm{X}$ & $(\mathrm{X})$ & \\
\hline
\end{tabular}




\section{Brock Center Roles}

\section{Editor-in-Chief}

The editor-in-chief is the person who works with the business, marketing and sales departments to set the editorial direction of the magazine and organization of the Brock Center. They work with their team to create an editorial vision, or brand, that creates an audience attractive to advertisers, if the magazine relies primarily on advertising for revenue. An editor-in-chief is responsible for creating attractive audiences, more so than quality content. To do this, they must deliver content that attracts a specific demographic -- especially if the content derives significant income from subscriptions -- but the end result must be delivering the right circulation. The editor-in-chief then communicates the business goals of the organization to the other associates and writers, helping to plan editorial calendars.

\section{Associates}

The associates directly supervise the additional contributors of the Brock Center. This person works to develop each type and issue's editorial, working with the other writers to finalize specific stories, angles and sources. The Associates usually write articles, and reviews all articles for content before they are published. The Associates often have subject expertise and contacts that allow them to shape an article's direction with the writer, down to recommending sources of information, such as industry research, organizations and sources.

\section{The Brock Center Staff}

The managing staff oversees the workflow of a magazine, creating a list of each magazine's feature, column and department stories and other editorial. The staff assigns articles and gives deadlines, word counts and article requirements. The Associates traffic all artwork, locating it, securing it, and working to make sure advertising materials arrive on time. Together the staff contacts all writers and advertising staff before material is due to ensure they are on schedule. If they find an article, artwork or an ad won't arrive on time, they will make arrangements to fill the void as discussed in the weekly meetings.

\section{Writing and Editing}

The team is responsible for pitching article ideas to selected writers and each other as well as guiding writer's ideas to fit the issue well. Most editors proofread and edit stories. Proofreading entails looking for objective errors; such as typos and grammatical errors. Story and line editing consists of improving the copy by rewriting sentences to make them flow better, organizing content to make the piece more logical, removing information that's not necessary, contacting the writer to ask for more information or editing to make sure an article fits in the allotted space. 


\section{Brock Center for Agricultural Communication Associate Contract}

By signing below, I agree to the following terms and conditions of employment with the Brock Center for Agricultural Communication. I understand failing to meet the terms and conditions described may jeopardize my employment and consequently lead to employment termination as determined by the Brock Center for Agricultural Communications Advisory Board.

Brock Associate Expectations of Employment:

1. Contribute 4-8 hours per week of work for the Brock Center. Editor-in-Chief is granted up to 20 hours per two-week pay period, Associate Editors are granted up to 16 hours per two-week pay period. At least half the hours worked should be accounted for in the Brock Center office.

2. Attend and participate in weekly staff meetings. Communicate necessary absences and tardiness ahead of the meeting date and time.

3. Provide guidance to volunteer writers through meetings, emails and exchanging necessary word count, story or blog angle, photography needs and deadlines.

4. Participate fully by completing outlined tasks in the role determined for the quarter or year; i.e.: Social Media, Designer, Editor or Advertising.

5. Manage equipment checkouts thoroughly to determine what items are leaving and returning to Brock Center and noting their condition.

6. Assist with the planning and hosting of the Brock Center Forum and attend the forum.

7. Occasionally attend community events or accommodate special project requests such as Rotary meetings, photography sessions, etc.

Associate Print Name

Associate Signature Date

Director Print Name

Director Signature

Date 


\section{Brock Center Planning}

At the beginning of each quarter, the associates need to create a schedule of their planned time at the Brock Center. A sample is below and should be placed outside the office for visitors to see. Each week, the Brock Center team gathers for a meeting. The 30 minutes to hour-long conversations keep the associates and director on the same page and brings the team to light of the latest needs, successes and next steps. Below are photos depicting the use of whiteboards for planning purposes. The boards get updated throughout the week and updates are shared at the weekly meetings.

Blogs are brainstormed and writers assigned with due dates to ensure a weekly blog occurs. Interested writers are listed as they come by the office expressing interest to help Brock Center. Story ideas are developed, writers assigned, and the associates each take on a few writers to guide through the process. The department or general topic of stories and blogs are also discussed to do the best job of sharing attention to a variety of college areas and industry needs. Advertisers are also tracked on the boards to determine size and placement of the ads within the layout of the stories within a few categories of the magazine.

\section{Ag Circle Editor’s Office Hours}

\begin{tabular}{|c|c|c|c|c|c|}
\hline & Monday & Tues & Wed & Thurs & Fri \\
\hline Taylor & $10: 00-12: 00$ & $10: 00-12: 00$ & $10: 00-12: 00$ & $10: 00-12: 00$ & $10: 00-2: 00$ \\
\hline Amanda & & 9:30-11:30 & $1: 00-3: 00$ & $1: 00-4: 30$ & $9: 00-10: 00$ \\
\hline Jordan & $\begin{array}{c}11: 00-12: 00 \\
1: 00-2: 00\end{array}$ & $10: 00-12: 00$ & $\begin{array}{c}10: 00-12: 00 \\
2: 00-4: 00\end{array}$ & & \\
\hline Kenna & & $\begin{array}{c}11: 00-1: 00 \\
2: 00-3: 00\end{array}$ & 1:00-3:00 & $\begin{array}{c}11: 00-1: 00 \\
2: 00-3: 00\end{array}$ & \\
\hline
\end{tabular}

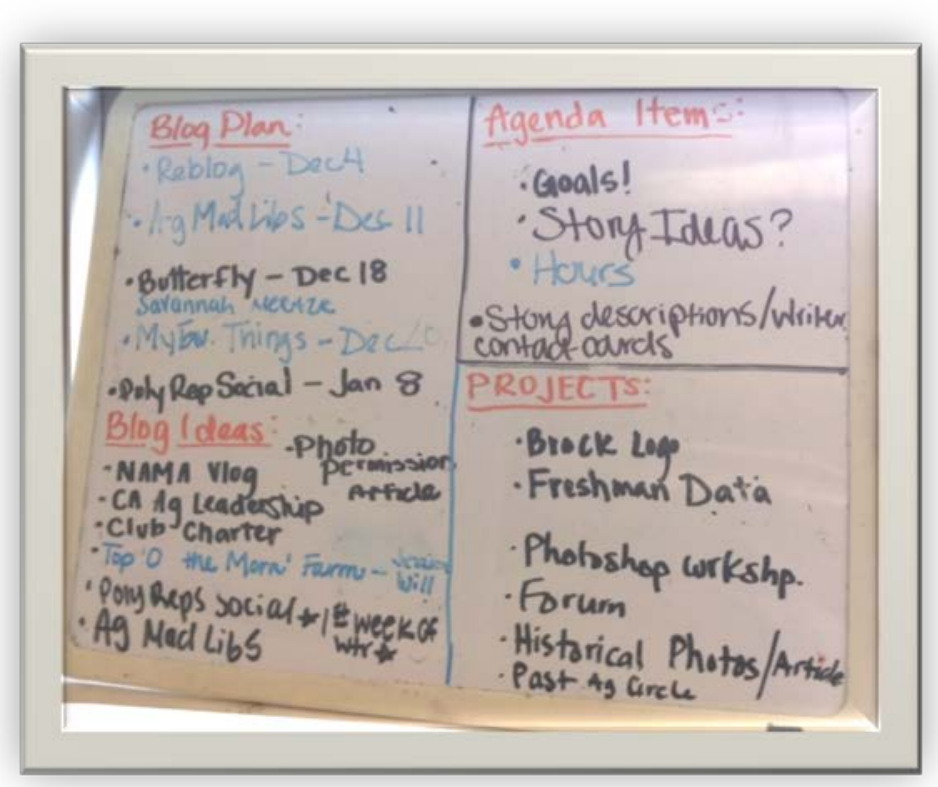

Figure 3: Blog Planning Whiteboard 


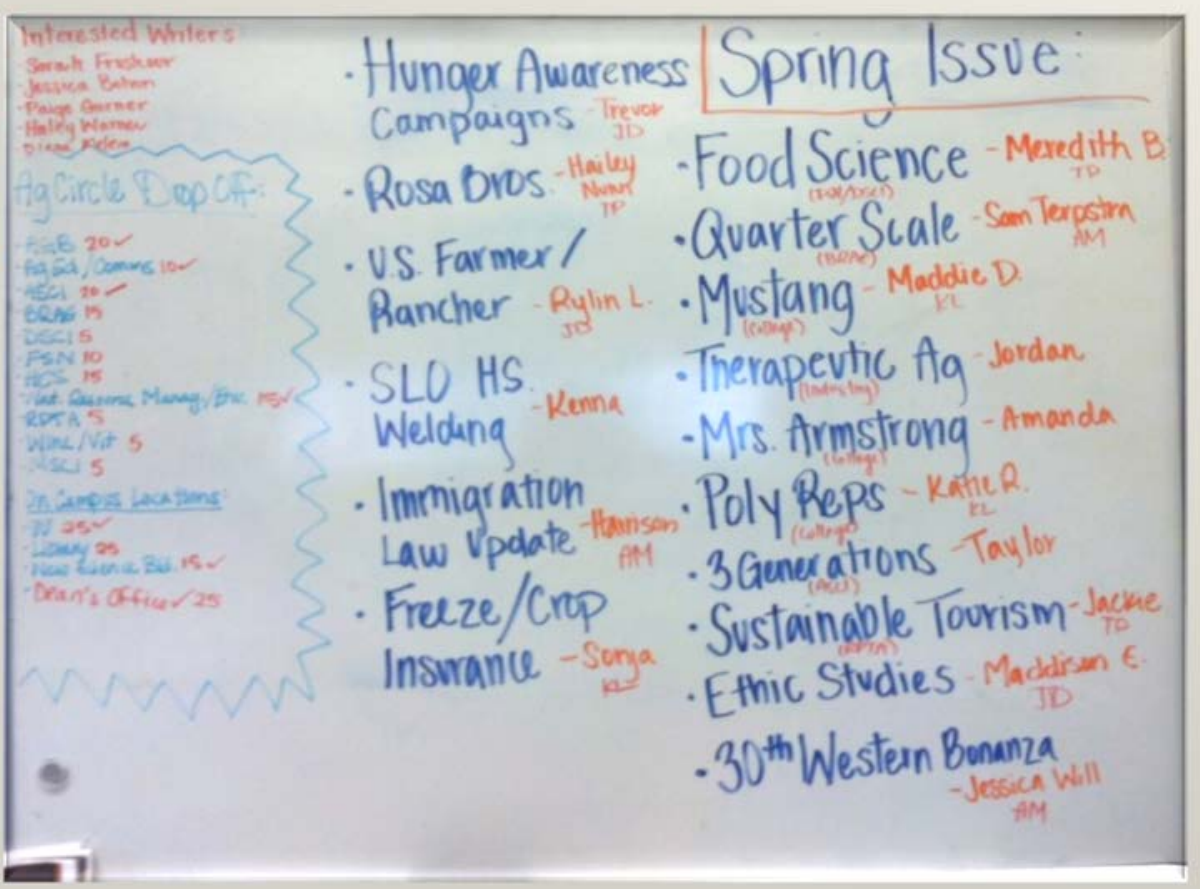

Figure 5: Story and Writer Planning Whiteboard

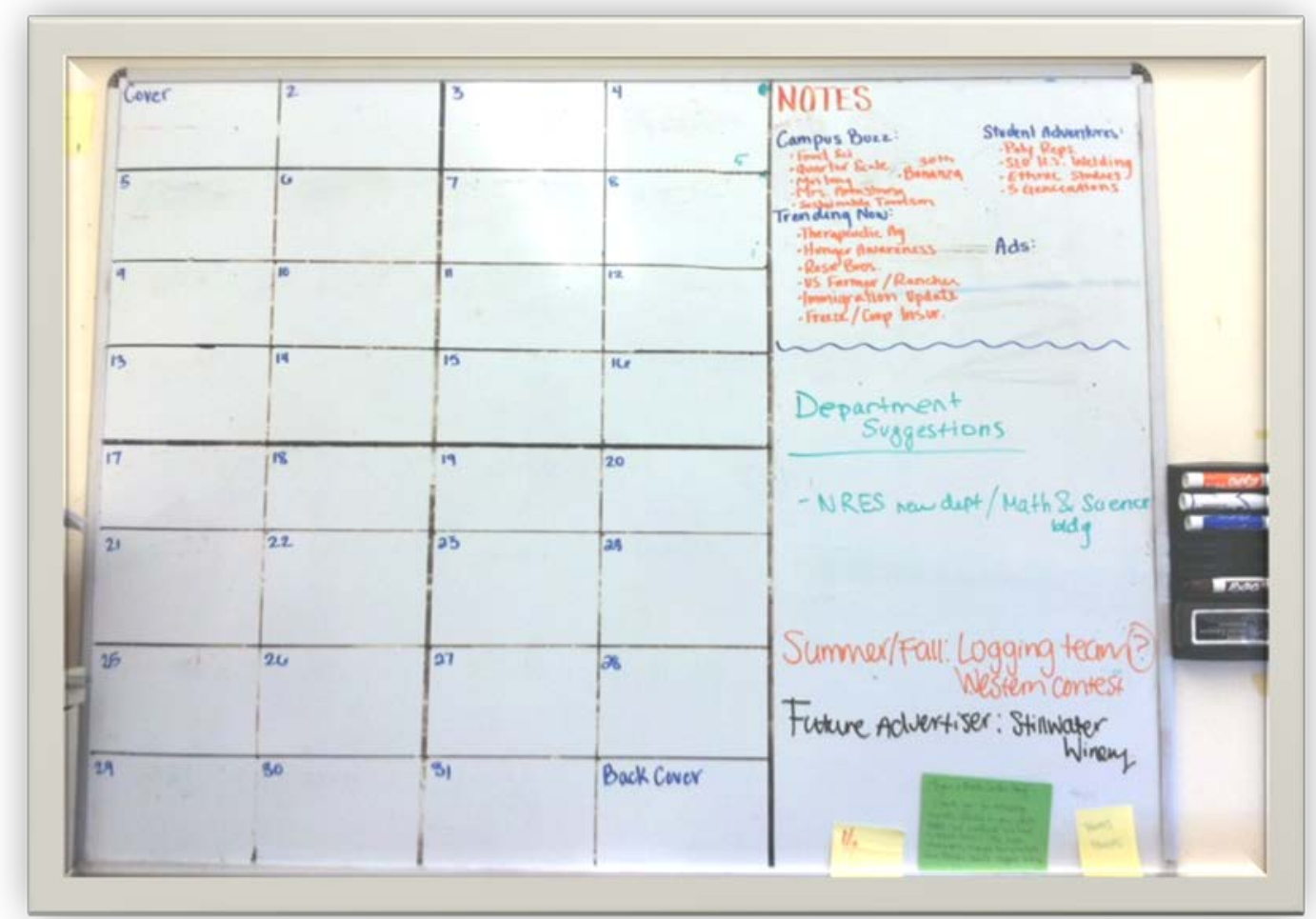

Figure 4: Magazine Page Layout Whiteboard 


\section{Equipment Replacement, Check Out Procedures, Inventory List}

The Brock Center is home to several great pieces of equipment. Students are able to check out the equipment to further their photography, interviewing and video skills. Below are plans for equipment replacement, check out procedures, use policy and an inventory list.

\begin{tabular}{|l|l|r|}
\hline Replacement Year & Items & Quantity \\
\hline $2013-2014$ & Replace/ purchase lithium batteries & 15 \\
\hline $2013-2014$ & Shelving units & 3 \\
\hline $2013-2014$ & Memory cards (8, 16, 32 gb) & 15 \\
\hline $2013-2014$ & Cords/ chargers Kodaks & 3 \\
\hline $2014-2015$ & Purchase/ replace camera batteries & 5 \\
\hline $2014-2015$ & Purchase additional Kodaks & 1 \\
\hline $2014-2015$ & Purchase/ replace Mac Pro & 1 \\
\hline $2014-2015$ & Lightbox photography equipment & 1 \\
\hline $2014-2015$ & Mic wireless replacement & 1 \\
\hline $2015-2016$ & Replace printer & 1 \\
\hline $2015-2016$ & Replace digital Canon & 15 next year \\
\hline
\end{tabular}

\section{Use Policy: Proposed 9/14/12}

\section{Hand Held Digital Video Camera Department Policy}

The department has hand held digital video cameras to be used to fulfill teaching and learning objectives related to department coursework and activities.

Cameras and related accessories (ie. Cords, plugs, chargers, batteries, memory cards and bags):

- Are available for use by the faculty, staff and students of the Department.

- Renter of equipment is responsible to replace lost, stolen or damaged equipment.

- Are to be labeled and given an identification number.

- Are to be kept in the storage room when not in use.

- Are to be checked out using the sign-out sheet. It is recommended cameras or equipment be reserved in advance using the calendar, to ensure availability. Students must secure faculty/staff approval to check out and return equipment.

- May be checked out no more than three days. Longer periods may be secured with Department approval.

- Equipment should be signed in and returned to their dedicated storage compartments for quick inventory and charging. 
Brock Center Equipment Inventory

\begin{tabular}{|l|l|l|l|}
\hline Cameras: & Lenses: & Video: & Other: \\
\hline Cannon 60D Camera (2) & 18-55 MM & Kodaks (20) & Sony Digital Voice Recorder \\
\hline Cannon EOS Rebel & $18-55 \mathrm{MM}$ & Flips (6) & Tripods (3 small, one large) \\
\hline & $55-250 \mathrm{MM}$ & Mini Flips (4) & iPad \\
\hline & $60 \mathrm{MM} \mathrm{Macro}$ & Panasonic HD Pro & Flash Housing \\
\hline & $50 \mathrm{MM}$ & & Cannon Zeikos Housing \& Mic boom \\
\hline
\end{tabular}

Check-Out Sheet Sample

\section{Brock Center Equipment Check-out}

\begin{tabular}{|l|l|l|l|l|l|l|l|}
\hline & & Date & & & & \\
Name & Phone & Out & Returned & Camera & Lens(es) & Other & $\begin{array}{l}\text { Associate } \\
\text { Initials }\end{array}$ \\
\hline & & & & & & & \\
\hline & & & & & & & \\
\hline
\end{tabular}




\section{Brock Associate Interview Questions}

Questions similar to those below, should be considered when screening potential Brock Center Associates for open positions.

1. Why would you like to join the Brock team?

2. What strength could you add?

3. Do you enjoy writing, editing or graphic design more? Can you explain?

4. How do you handle deadlines? Stress?

5. What is a skill you'd like to work on and further develop at Brock?

6. What would you do differently in the Brock Center to further it' mission?

7. What's your favorite part about the Brock Center?

\section{Brock Associate Assessment Questions}

Questions similar to those below, should be asked at the end of each Spring quarter. Associates are to submit their responses anonymously prior to leaving for summer break. Adjustments to the Brock Center can be gleaned from their responses.

During your time in the Brock Center this past year, identify the program's strengths and weaknesses by answering the following questions. Your honest input is appreciated.

1. How accessible was the Brock Center Director? Were there times you needed more or less guidance?

2. Did you have adequate equipment, supplies and workspace to accomplish your tasks?

3. What items are needed to improve the Center?

4. What are your thoughts towards the Brock Director's relationship with your team? Did you have an open relationship with maybe too much personal information shared or did you need a more personal relationship to help you as a student?

5. During student advising sessions, does the Brock Center/office door need to be closed?

6. Did you receive adequate pay for your time and effort put into Brock Center?

7. What would you still like to learn about magazine production that you weren't able to for any reason?

8. Would you like video production to be a part of the Brock Center?

9. What are your thoughts about using Social Media for the Brock Center? Ideas/changes?

10. Were Brock Center meetings productive? Ideas/changes?

11. Finally, what goals would you like to see carried out for the incoming staff? 


\section{Brock Center Associate Meeting Agenda Sample}

Agendas can vary from team to team. Standard items of discussion should always include deadlines approaching, writer and story updates, blog plans, special project reports, and timecards filled out.

\section{Brock Center Associates Meeting}

Time: 6pm, Saturday December 3, 2011

Location: Leslie's home

Called by: Megan Silcott

I. Attendees

1. Leslie Friend

2. David Jones

3. Carrie Isaacson

4. Jennifer Ray

5. Megan Silcott

II. Discussion Items about Fall Issue and Winter Plans

A. Fall Successes

1. Photo driven Fall issue was good and design was very appealing

2. Magazines were premiered at the CAFES Holiday Luncheon

3. Squares at top of pages created consistency

4. QUICK turnaround!!!

B. Winter Plans

1. Winter Story writers are well under way, good response from first issue success!

2. Plans to bid the next issue for local printing to get a hard copy proof Winter due dates may need to be adjusted for conference trips.

a. Editing Thoughts

i. An editing page needs to be created and attached to each story for proofing rounds.

ii. reviewed by Donetta Rosson and Ellen Cohune

iii. initial edits by the delegated Brock Associate

3. Rename issue to match the timing of printing.

4. Need one page stories: ex is Dirty Job blurbs

5. Winter Water Forum planned for late February to be hosted by Brock

6. Photography workshop weekend to be planned for early Winter quarter

7. Video blogging and short written blogs need to be added to the website

8. Megan needs to check on pay scale for David/hours available for staff

9. April 1 is the Critique Contest due date

10. Megan needs to check on paying for PD Conference in February

11. Next student spotlight to be Cortney Newby

12. Telling Your Ag Story to be planned for Spring quarter

III Next Meeting: Jan, 5, 2012, 11 am in Brock Center 
The first ever Past Brock Associate Survey was delivered via the Brock Center Survey Monkey account on November 25, 2013. The purpose of the survey is to gather ideas, history and comments from past associates that can further the mission of the Brock Center. The following questions were sent to 24 past associates from the early 1990s to present. Results will be gathered and shared with both the College of Liberal Arts and College of Agriculture, Food and Environmental Sciences, as well as the Brock Center Advisory Board. 
Help us understand your perspective of the Brock Center.

\section{*1. My connection to the Cal Poly Brock Center is: (Select all that apply)}

Cal Poly Faculty

Other University Faculty

Past Brock Center Director

Department Advisory Member

Alumni

Past Brock Center Associate

Current Ag Communications/Ag Science Student

Current Journalism Student

Other (please specify) 


\section{Magazine \& Blog}

Please visit our most recent issue of Ag Circle magazine:

http://issuu.com/brockcenter/docs/agcirclespring2013

Our blog can be viewed at: http://brockcenter.wordpress.com/

\section{What changes would you like to see to the Ag Circle magazine? (Select as many as} apply.)

$\square$ Increase Length

Decrease Length

Change the Page Size

Other (please specify)

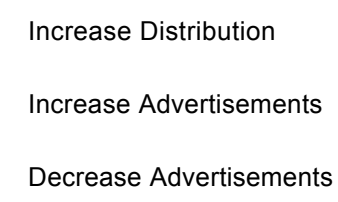

3. What changes would you like to see to the content of Ag Circle magazine? (Select as many as apply.)

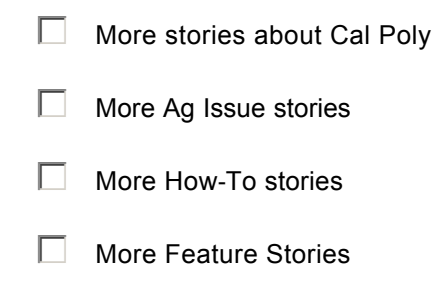

Other (please specify)

\section{What suggestions do you have for the content of the Brock Center Blog?} Visit the blog here: http://brockcenter.wordpress.com (Select as many as apply.)

More posts about Cal Poly

$\square$ More Ag Issue posts

$\square$ More How-To posts

$\square$ More Video Posts

More interaction with other ag blogs

No Changes

Other (please specify) 


\section{Workshops \& Discussion Forums}

5. Please rank the following potential workshops/seminars in order of your preference. (1-

8)

\begin{tabular}{|l|l|}
\hline Adobe Photoshop (Photo Editing) \\
\hline Adobe InDesign (Designing Layouts) \\
\hline Adobe Dreamweaver (Web Design) \\
\hline$\square$ Cow to Interview a Story Source \\
\hline$\square$ Basic Photography \\
\hline$\square$ Business Etiquette/ International Business Etiquette \\
\hline$\square$ Participation in Agricultural Lobbying (Legislative and Regulatory Issues) \\
\hline$\square$
\end{tabular}

6. How many workshops/seminars would you like to see Brock Center host per year (not including discussion forums)?
$\bigcirc 1$
$\bigcirc 2$
$\bigcirc 3$
$\bigcirc 4$
$\bigcirc 5$

7. Would you be willing to pay for workshops/seminars?

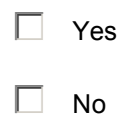

8. For a two-hour professional workshop, (a topic and structure that would enhance your professional development) how much would you be willing to pay?

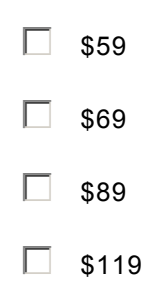


9. Currently, the Brock Center hosts one annual forum on a current agricultural topic. How many discussion forums would you like to see per year (not including workshops/seminars)?

$\bigcirc 1$

$\mathrm{O}_{2}$

3

$\mathrm{O}_{4}$

$\bigcirc$

10. Please rank the following potential agricultural discussion forums in order of your preference. (1-10)

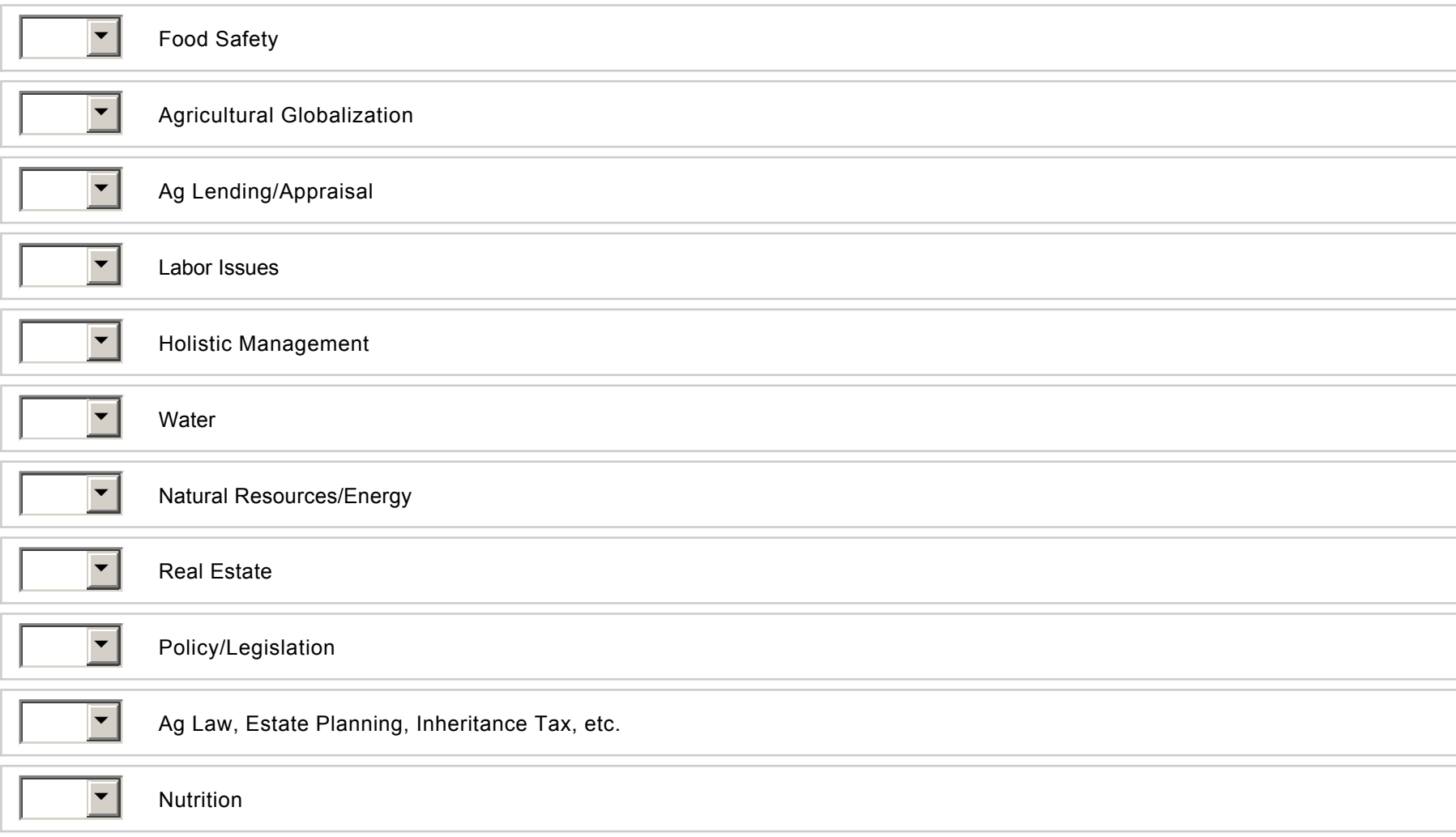




\section{Branding, Advertising \& Reach}

11. If the Brock Center sold the following merchandise with their logo, what items would you consider purchasing? (Select as many as apply.)

$\square$ Coffee Mug

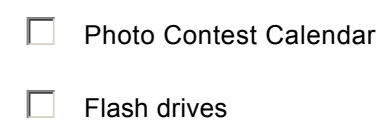

-Shirt

lash drives

Notepads/Notebooks

Other (please specify)

12. Write-In (optional): What could the Brock Center do to improve its professional image as a center for student learning and a means of bridging the gap between agriculture and the media?

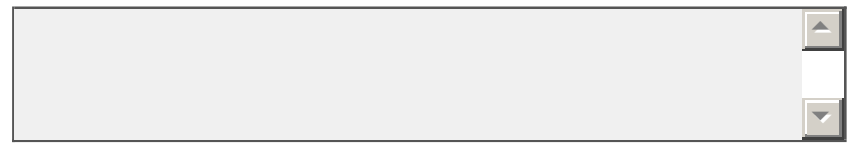

13. 2012/2013 Ag Circle Advertisers include: Agroculture Liquid Fertilizer, Carolina Evangelo Communications, Gallo Winery, JB Dewar, Mission Produce, PRP Companies and Yosemite Farm Credit.

Do you have suggestion(s) for long-term advertisers? If yes, please list any suggestion(s) here:

14. Ag Circle magazine is distributed on campus and at trade shows. It is also mailed to every county Farm Bureau office, every agricultural high school and college program in California and a small list of fans. Copies are also mailed to other universities with agricultural communications programs.

Write in: (optional) Where else would you recommend Ag Circle be distributed?

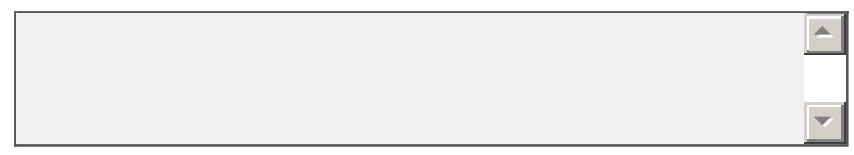

15. Do you have suggestion(s) for creative ways to fund increased magazine distribution? If yes, please list any suggestion(s) here: 


\section{Additional Comments or Suggestions}

16. Please feel free to use this space to share additional comments, feedback or suggestions for the Brock Center (optional). Thank you for taking our survey!

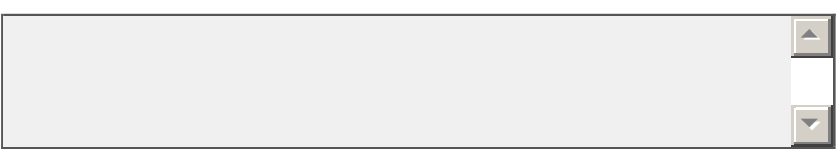




\section{Advisory Council}

The Brock Center Advisory Board will be reestablished this academic year. Through the work of past Brock Associate, Jennifer Ray, (current Graduate Assistant at Kansas State University), past College of Agriculture, Food and Environmental Sciences (CAFES) Dean Wehner, College of Liberal Arts (CLA) Dean Doug Epperson, Journalism Department Head Mary Glick and Agricultural Education and Communication Department Head Bill Kellogg, the following discussion took place and offered structure and feedback for the Advisory Board.

Brock Center should reestablish its own Advisory Board through collaboration between the CLA and CAFES. The board members may overlap with the Agricultural Education and Communication Department Advisory Council in some cases. The important difference is that the Brock Center Advisory Board will be focused directly on the Center, which will allow for growth. The Agricultural Education and Communication Department and Journalism Departments will need to begin the process of reestablishing the Advisory Board by making recommendations for members.

\section{Goals for the Advisory Board:}

- Increase Collaboration between CLA and CAFES

A Brock Center Advisory Council can find ways to increase collaboration between the CLA and CAFES. One way to generate ideas on how to do this is to examine other Agricultural Communication programs across the nation and how they collaborate with their Journalism program.

- Define strategies to be used by the Brock Center

A Brock Center Advisory Council can develop and define strategies for the Brock Center regarding: industry research, magazines production, blog management, outreach activities, discussion forums and special projects for private entities, non-profit organizations and Cal Poly.

- Discuss specific plans for making changes to realign with bylaws

- Provide feedback and recommendations on magazine content and layout

- Discuss and analyze only the Brock Center, which, enables the Agricultural Education and Communication Department Advisory Council sub-committee to focus on discussing the Agricultural Communication curriculum

- Inform members of the Brock Center's history and current practices

- Gain industry support in expanding the role of the Brock Center

- Help the Brock Center become a resource hub for the industry to offer profitable projects (becoming more sustainable, project generation)

- Gather industry feedback about technology and editing processes applied

- Discuss the role of the Director and provide Director with guidance 


\title{
Brock Center Bylaws
}

\section{CALIFORNIA POLYTECHNIC STATE UNIVERSITY \\ BROCK CENTER FOR AGRICULTURAL COMMUNICATION}

BYLAWS

The bylaws of the Brock Center for Agricultural Communication are operative within policy established by the Board of Trustees of The California State University and California Polytechnic State University.

\section{Article I}

NAME

The name of this organization shall be: The Brock Center for Agricultural Communication and is referred to in these bylaws as the Center.

\author{
Article II \\ MISSION \& AUTHORITY
}

Section A. Mission

The mission of the Center, which carries the name of benefactors James and Martha Brock, is to create a bridge of communication among the agricultural industry, the media and the public. As a facilitator of this essential dialogue, the Center draws directly on the technical expertise of the College of Agriculture, Food and Environmental Sciences and the academic resources of the College of Liberal Arts. The Brock Center's prime focus is on the preparation of the professional communicators for California’s agriculture industry.

Section B. Authority

The Center was established by the university under campus administrative manual policy and practices. Its designation recognizes that the Center is one of those areas of excellence in the university in which.the application of knowledge requires special interdisciplinary effort. Such designation also indicates that the Center has the support of the entire academic community. 


\section{Article III}

\section{ASSOCIATIONS WITH CENTER}

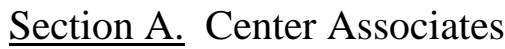

Employees and students of the university are eligible to be Center Associates under guidelines set by the Center Director in consultation with the Advisory Board.

\section{Section B. Support Associates}

Individuals, groups, associations, and public and private business entities actively involved with the Center are eligible to be Center Support Associates under guidelines set by the Center director in consultation with the Advisory Board.

Associates are encouraged to be active in the Center through program/project involvement and resource development efforts.

\section{Article IV}

\section{ADMINISTRATION}

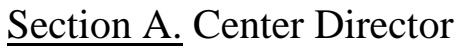

Management of the Center shall be the responsibility of a director, who shall have faculty rank within the College of Agriculture, Food and Environmental Sciences or the College of Liberal Arts, together with the education, experience and skill requirements determined by the Advisory Board

The Center Director is responsible for:

1. providing administrative support for the overall daily operation of the Center;

2. planning, monitoring and accounting of the Center budget;

3. preparing and submitting annual and other required reports to the university; and

4. serving as an agricultural industry liaison.

The director is appointed by the Vice President for Academic Affairs and reports to the deans of the colleges of Agriculture, Food and Environmental Sciences and Liberal Arts. Major policy or program matters may be referred to the University Vice President for Academic Affairs. 


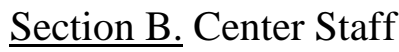

The Center may engage center staff on a volunteer, consultant or employment basis to perform Center tasks, consistent with authorized projects and budgets.

\section{Article V}

\section{ADVISORY BOARD}

Section A. Role and Functions

The Center Advisory Board shall advise the college deans and the Center director on major policy, plans and activities of the Center, and may assist in resource development and interaction with Support Associates. The board shall also serve as a consultative committee in the selection of a Center Director.

Section B. Composition

The Center Advisory Board shall be composed of seven voting members: the director as board chairperson; and six members chosen on equal basis by the deans of the colleges of Agriculture, Food and Environmental Sciences and Liberal Arts. Members appointed by the deans shall serve staggered three year terms. The Center Advisory Board shall meet at least once each year. Board meetings shall be held under guidelines adopted by the Board. A majority of the members constitute a quorum. Supporting Associates may attend and participate in board meetings as non-voting members.

\section{Article VI}

FISCAL AFFAIRS

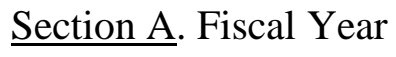

The Center fiscal year shall be that of the Cal Poly Foundation.

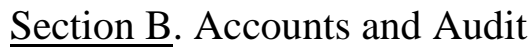

Center financial records shall follow University and Foundation budget accounting and audit practices. 


\section{MISCELLANEOUS}

Section A. Dissolution

Upon dissolution, Center assets net of obligation shall be held in trust by the Foundation for the University

Section B. Amendments

Amendments to these Bylaws may be recommended to the university by the director or upon a two-thirds affirmative vote of the Advisory Board.

APPROVED:

for University

Effective Date:

RECOMMENDED BY:

Director

Advisory Board 


\section{Journalism Code of Ethics}

*Adapted from the Society of Professional Journalists, 2013

\section{Preamble}

Members of the Society of Professional Journalists believe that public enlightenment is the forerunner of justice and the foundation of democracy. The duty of the journalist is to further those ends by seeking truth and providing a fair and comprehensive account of events and issues. Conscientious journalists from all media and specialties strive to serve the public with thoroughness and honesty. Professional integrity is the cornerstone of a journalist's credibility. Members of the Society share a dedication to ethical behavior and adopt this code to declare the Society's principles and standards of practice.

\section{Seek Truth and Report It}

Journalists should be honest, fair and courageous in gathering, reporting and interpreting information.

\section{Journalists should:}

- Test the accuracy of information from all sources and exercise care to avoid inadvertent error. Deliberate distortion is never permissible.

- Diligently seek out subjects of news stories to give them the opportunity to respond to allegations of wrongdoing.

- Identify sources whenever feasible. The public is entitled to as much information as possible on sources' reliability.

- Always question sources' motives before promising anonymity. Clarify conditions attached to any promise made in exchange for information. Keep promises.

- Make certain that headlines, news teases and promotional material, photos, video, audio, graphics, sound bites and quotations do not misrepresent. They should not oversimplify or highlight incidents out of context.

- Never distort the content of news photos or video. Image enhancement for technical clarity is always permissible. Label montages and photo illustrations.

- Avoid misleading re-enactments or staged news events. If re-enactment is necessary to tell a story, label it.

- Avoid undercover or other surreptitious methods of gathering information except when traditional open methods will not yield information vital to the public. Use of such methods should be explained as part of the story

- Never plagiarize.

- Tell the story of the diversity and magnitude of the human experience boldly, even when it is unpopular to do so.

- Examine their own cultural values and avoid imposing those values on others.

- Avoid stereotyping by race, gender, age, religion, ethnicity, geography, sexual orientation, disability, physical appearance or social status.

- Support the open exchange of views, even views they find repugnant. 
- Give voice to the voiceless; official and unofficial sources of information can be equally valid.

- Distinguish between advocacy and news reporting. Analysis and commentary should be labeled and not misrepresent fact or context.

- Distinguish news from advertising and shun hybrids that blur the lines between the two.

- Recognize a special obligation to ensure that the public's business is conducted in the open and that government records are open to inspection.

\section{Minimize Harm}

Ethical journalists treat sources, subjects and colleagues as human beings deserving of respect.

\section{Journalists should:}

- Show compassion for those who may be affected adversely by news coverage. Use special sensitivity when dealing with children and inexperienced sources or subjects.

- Be sensitive when seeking or using interviews or photographs of those affected by tragedy or grief.

- Recognize that gathering and reporting information may cause harm or discomfort. Pursuit of the news is not a license for arrogance.

- Recognize that private people have a greater right to control information about themselves than do public officials and others who seek power, influence or attention. Only an overriding public need can justify intrusion into anyone's privacy.

- Show good taste. Avoid pandering to lurid curiosity.

- Be cautious about identifying juvenile suspects or victims of sex crimes.

- Be judicious about naming criminal suspects before the formal filing of charges.

- Balance a criminal suspect's fair trial rights with the public's right to be informed.

\section{Act Independently}

Journalists should be free of obligation to any interest other than the public's right to know.

\section{Journalists should:}

- Avoid conflicts of interest, real or perceived.

- Remain free of associations and activities that may compromise integrity or damage credibility.

- Refuse gifts, favors, fees, free travel and special treatment, and shun secondary employment, political involvement, public office and service in community organizations if they compromise journalistic integrity.

- Disclose unavoidable conflicts.

- Be vigilant and courageous about holding those with power accountable.

- Deny favored treatment to advertisers and special interests and resist their pressure to influence news coverage.

- Be wary of sources offering information for favors or money; avoid bidding for news. 


\section{Be Accountable}

Journalists are accountable to their readers, listeners, viewers and each other.

\section{Journalists should:}

- Clarify and explain news coverage and invite dialogue with the public over journalistic conduct.

- Encourage the public to voice grievances against the news media.

- Admit mistakes and correct them promptly.

- Expose unethical practices of journalists and the news media.

- Abide by the same high standards to which they hold others. 


\section{Brock Center Activities and Projects}

Brock Center projects are limitless. Careful consideration must be given to projects proposed and thought of in order to align projects with the mission and goals of the Brock Center.

2013-2014 Tentative Activities and Projects

o Blog/Social Media Projects

o Website and Video Projects

o Ag Circle Projects

o Community Forum Projects

o Past Associate Surveys

o Agricultural Issue Surveys/Research

o Educational Outreach

o Promotion and Writing Support

o Mini Photo Sessions

o Historical Photos of Cal Poly Agriculture

o Historical Interviews of Retirees 


\section{Blog Maintenance}

- Weekly blogs have been posted on Wednesdays, historically.

- Blog topics and writers are assigned during weekly Brock Center meetings. Anyone is welcome to blog for the Brock Center but the topic must circle back to agriculture.

- Blogs are composed and edited in time to post by Wednesday afternoon.

- Blogs should be read by the advisor before final posting.

- Blog comments need to be monitored.

- Once posted, blog advertising takes place via social media.

- Blogs can be extensions of past projects, carry over from Ag Circle stories, offer remaining interview content, showcase a video project, and promote any and all forms of agriculture near and far.

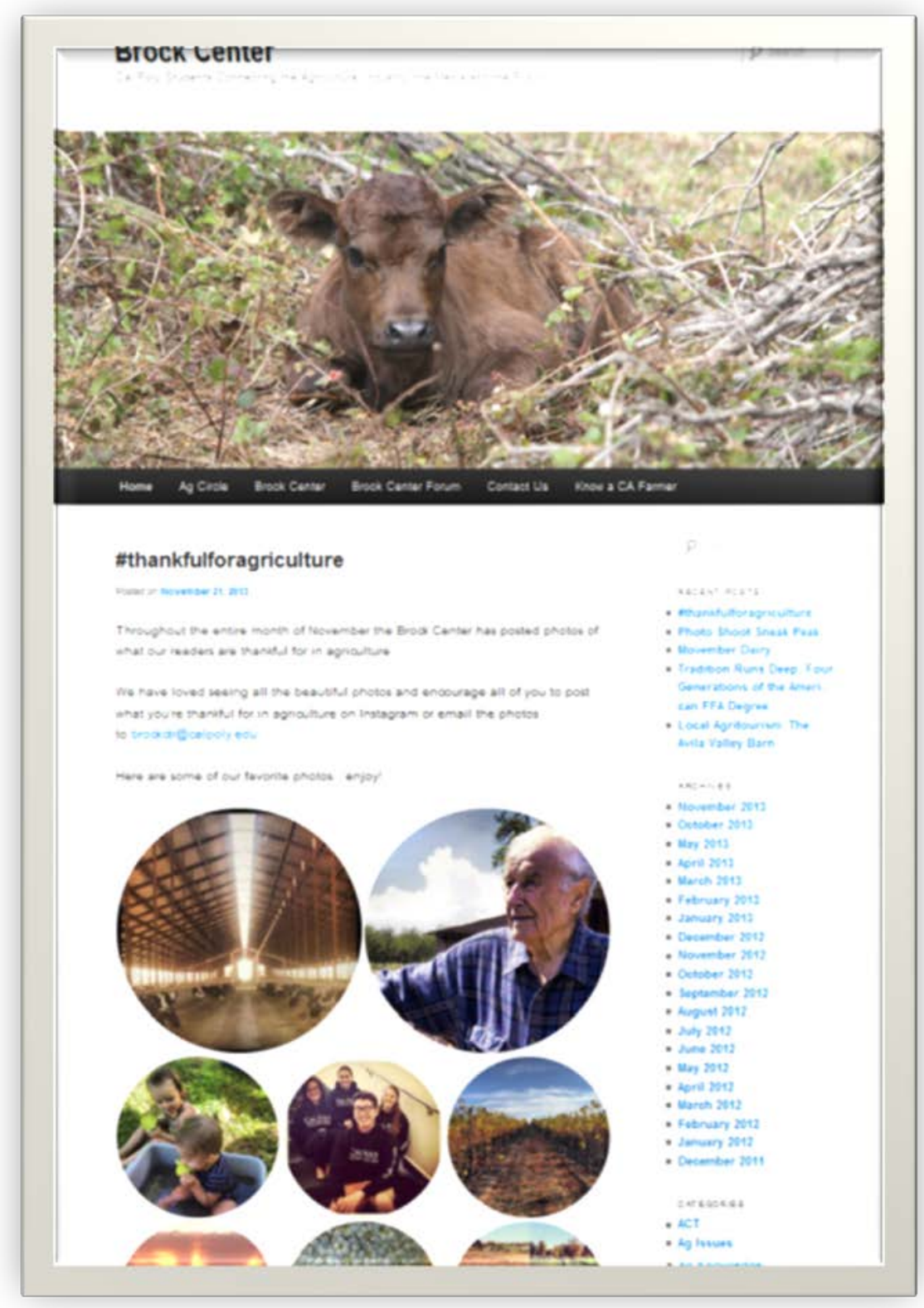

Figure 6: Brock Center blog snapshot Fall 2013 


\section{Website Maintenance: www.brockcenter.calpoly.edu}

The Brock Center website was transferred from Dream Weaver to Cal Poly's Drupal site over Winter break 2012. The site needs to be continually updated to be more useful and a better learning tool for the associates. Drupal is a much more user-friendly site and can be maintained on or off-campus as it has a web-based log in. The director has the ability to add associates or other users to the editing profiles with limited or full access to work on the website.

Two projects that can be created from the website maintenance are updating the agricultural resource links, and making the magazine and blog pieces more interactive by posting interviews and videos to the website in addition to the blog site.

Cal Poly offers Drupal training sessions to keep the sites updated, useful and aligned with disability requirements.

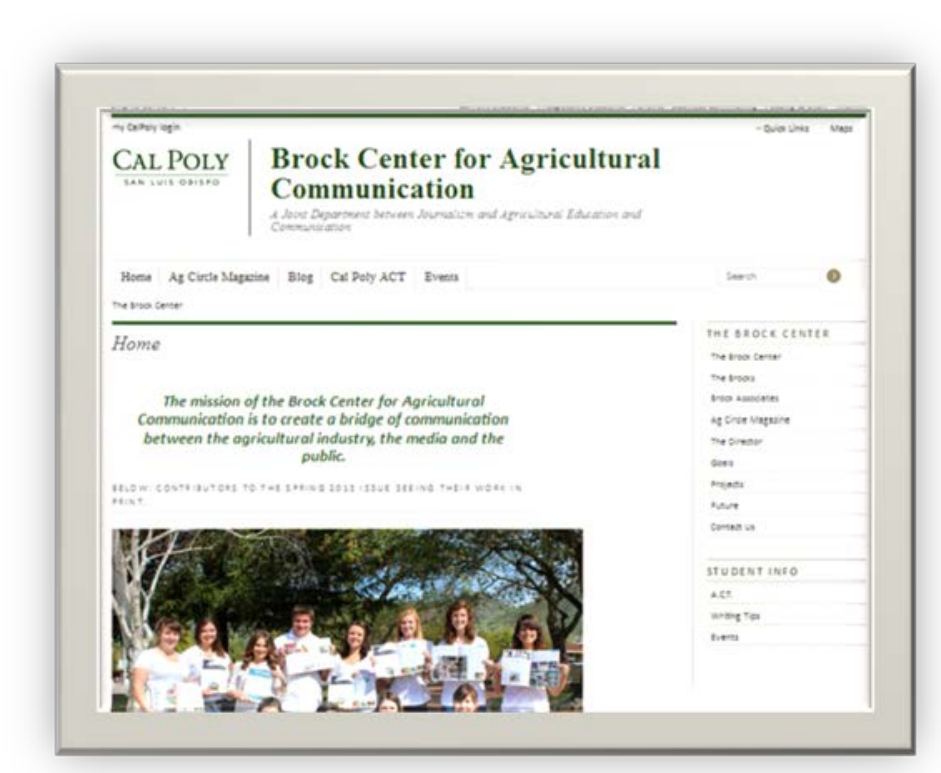

Figure 7: Snapshot of the homepage for www.brockcenter.calpoly.edu 


\section{Forum Planning Procedures and Timeline}

- Summer: Identify several potential topics to shape the forum.

- Early Fall: Propose topics and potential speakers to both Agricultural Education and Communication Department staff and Journalism Staff.

- Early Fall: Reserve facility for event. PAC Pavilion has worked well. At least 100 seats, microphone, screen and projector needed. See sample Request for Use form from 2012.

- Fall: Propose finalized speaker(s) and topic to both Deans of College of Liberal Arts and CAFES.

- Late Fall: organize speaker forms, travel and lodging.

- Late Fall: coordinate payment and advertising of paid sessions for speaker if needed.

- Winter Break: develop press releases and fliers to promote event.

- Early Winter: order campus catering

- Winter: Advertise forum through all media including University News, Mustang Media, community calendars, CPTV, KCPR radio, social media: Instagram, blog, Facebook and Twitter.

- Winter: organize speaker thank you gifts. Coordinate some floral décor, pens, sign in and note sheets for guests. Have Ag Circle issues available.

- Winter: conduct forum. Request slides from presenters to share as requested and available.

- After event: Send thank you notes to guest speakers and facility staff.

- After event: Recap the positive and negative event pieces with Brock Center staff, and both departments. 


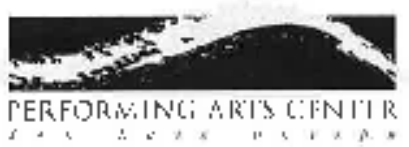

REOLEST FOR USE

CHRISTOPIER COILN CENTER SAN 1.IS OHISPO, CALIIORNIA

\begin{tabular}{|c|c|c|c|c|c|c|c|}
\hline \multicolumn{2}{|c|}{ DAY(S) of WELK } & Wedrn & 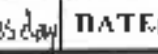 & s) n F.VFiN & & 12 & \\
\hline \multicolumn{8}{|c|}{ EYLXTITLRFORMANCE IXFORMLTION } \\
\hline \multicolumn{3}{|c|}{ Naums ol Performunceletent } & \multicolumn{5}{|c|}{ Water Forum } \\
\hline \multicolumn{3}{|c|}{ 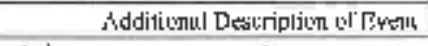 } & \multicolumn{5}{|c|}{ 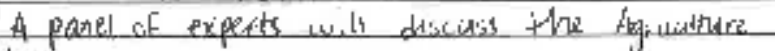 } \\
\hline \multicolumn{8}{|c|}{ Woiver impacting agrivilure. } \\
\hline \multicolumn{8}{|c|}{\begin{tabular}{l|l|l} 
Type of Eventipertajnatise & \\
\end{tabular}} \\
\hline \multirow{2}{*}{\multicolumn{2}{|c|}{ 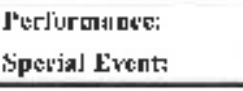 }} & Dunce & \multirow{2}{*}{\multicolumn{5}{|c|}{ 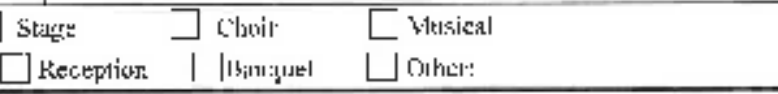 }} \\
\hline & & Hecting & & & & & \\
\hline \multicolumn{8}{|c|}{ 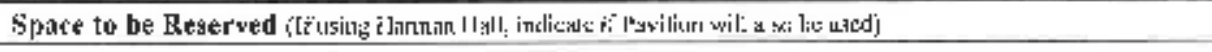 } \\
\hline \multicolumn{8}{|c|}{ 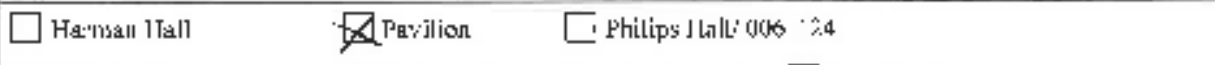 } \\
\hline \multicolumn{8}{|c|}{ 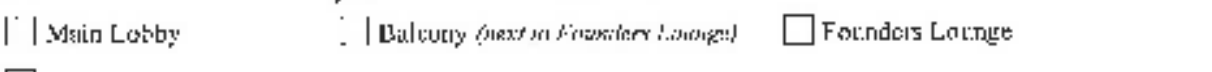 } \\
\hline \multicolumn{8}{|c|}{ 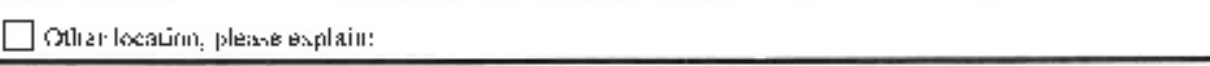 } \\
\hline \multicolumn{8}{|c|}{ 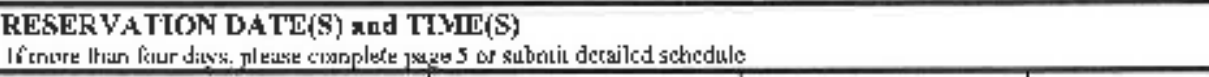 } \\
\hline \multicolumn{3}{|c|}{---Kus Lrsution Datu(s)-.- } & \multicolumn{2}{|c|}{- -P'ru FrenuI--- } & \multicolumn{2}{|c|}{ 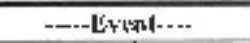 } & Pust Ev'ellt-- \\
\hline $\begin{array}{l}\text { Rescin } \\
\text { wali:s: }\end{array}$ & 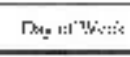 & 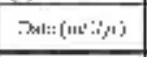 & 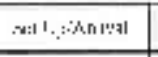 & inel l.: r.:A & 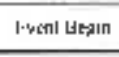 & Liztent Or.d & 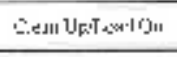 \\
\hline \multirow{2}{*}{ I } & Wed. & 나리 12 & Lan & 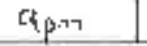 & b.pen & epr & \\
\hline & t.tos as. & Kahoarsal & \multicolumn{5}{|c|}{ 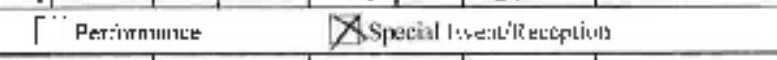 } \\
\hline \multirow{2}{*}{2} & & & & & & & \\
\hline & I is is $x$ & |Rshenrsal & \multicolumn{2}{|c|}{ L-Per inrminnte } & \multicolumn{3}{|c|}{ 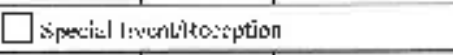 } \\
\hline \multirow{2}{*}{3} & & & & & & & \\
\hline & r ris i: il & 2klearsal & \multicolumn{2}{|c|}{ E Emerormance } & \multicolumn{3}{|c|}{ 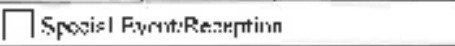 } \\
\hline \multirow[t]{2}{*}{4} & & & & & \multirow{2}{*}{\multicolumn{3}{|c|}{ 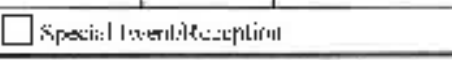 }} \\
\hline & . I:Is is a & | Zsahenrsn! & \multicolumn{2}{|c|}{ [ Perr ïrmiıntre } & & & \\
\hline
\end{tabular}

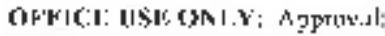

Dale: $\mathrm{FOH}$

Revised Sepletuber I. 20l J 
Brock Center Forum Catering Order 2013

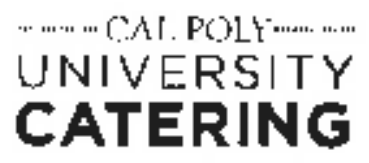

\begin{tabular}{|c|c|}
\hline \multicolumn{2}{|c|}{ Catering Contract } \\
\hline \multicolumn{2}{|c|}{$2 / 27 / 2013$} \\
\hline \multicolumn{2}{|c|}{$0.0100004 / U N I V$} \\
\hline \multicolumn{2}{|c|}{ PAC Pavilion } \\
\hline \multirow{2}{*}{\multicolumn{2}{|c|}{$\begin{array}{r}\text { Grew Setup 4:30 pm - 6:00 pm } \\
\text { Event Start 6:00 pm }\end{array}$}} \\
\hline & \\
\hline \multirow{3}{*}{\multicolumn{2}{|c|}{ 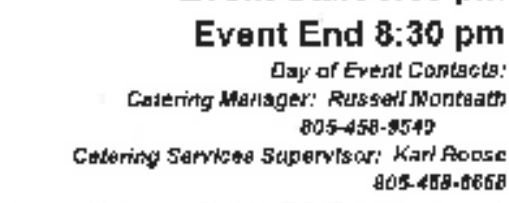 }} \\
\hline & \\
\hline & \\
\hline & \\
\hline (Ki:S; 7Sr-2ny? & 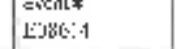 \\
\hline 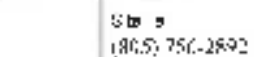 & $\begin{array}{l}\text { Si.ents } \\
\text { ISI: ÁtLLi }\end{array}$ \\
\hline $\begin{array}{l}\text { Coxpony } \\
\text { Inuffer }\end{array}$ & \\
\hline
\end{tabular}

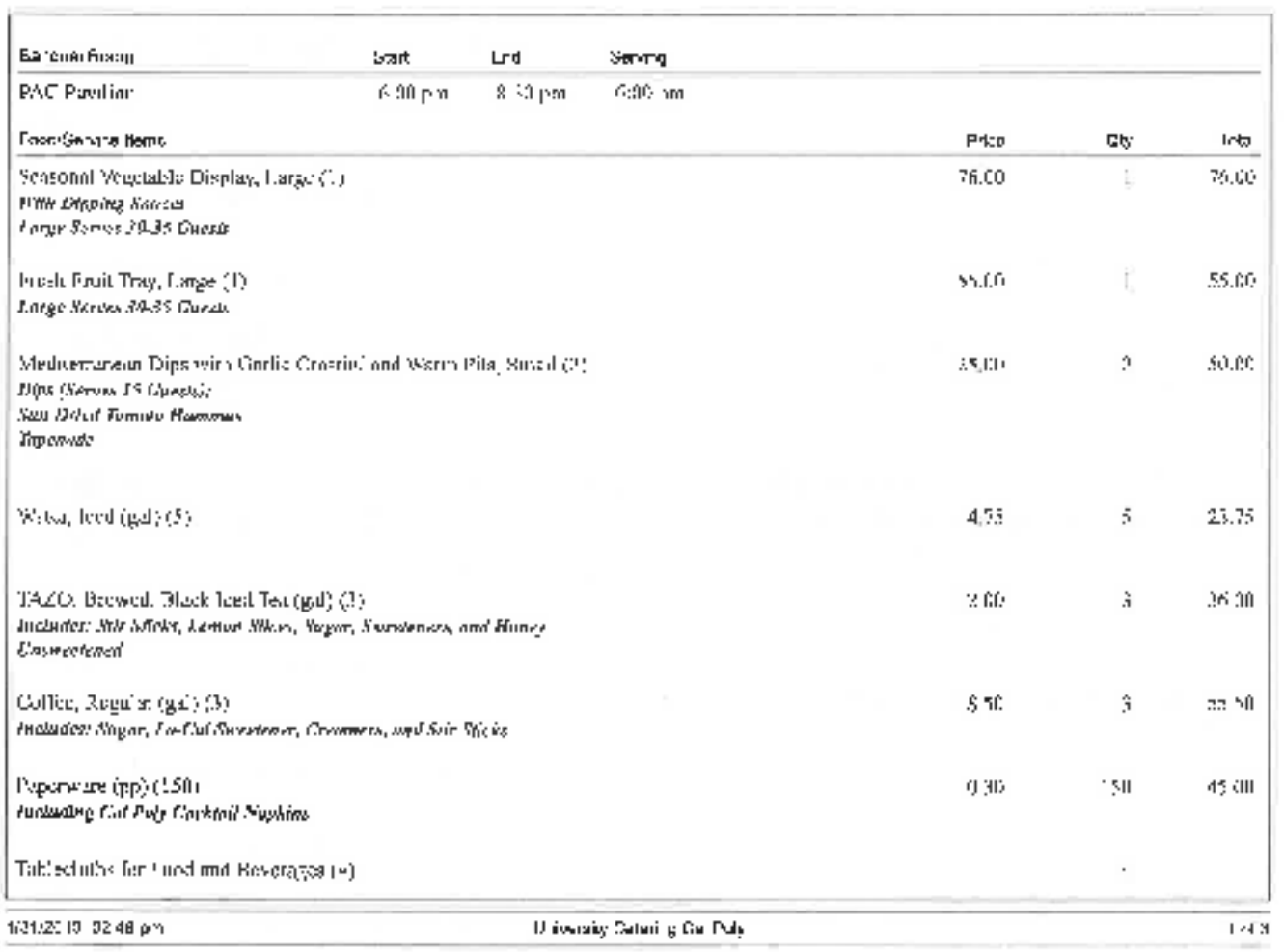




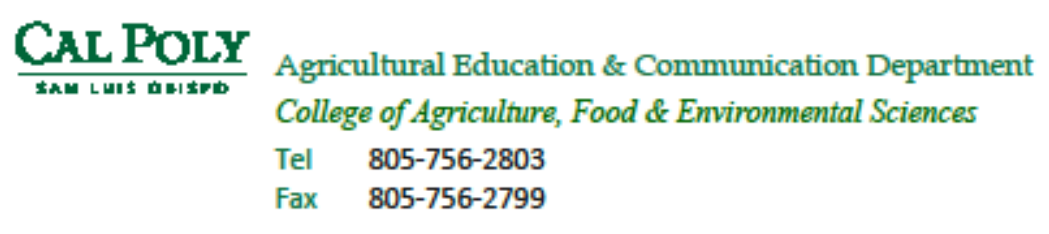

December 17, 2012

Orange County Produce, LLC

c/o Mr. Nicholas Snow

11405 Jeffrey Road

Irvine, CA 92602

Dear Mr. A.G. Kawamura:

Greetings from the Brock Center for Agricultural Communication at Cal Poly, San Luis Obispo. Im writing to seek your assistance and possibly, your participation. On Wednesday, February 27, 2013, from 6:00-8:30pm the Brock Center at Cal Poly will be hosting a community forum on the topic of Food Systems.

Our more focused topic is the implications food policy (including food safety, transportation, imports and exports) have on California agriculture. In 2012, the Brock Center hosted a forum about water regulations. Around 150 people attended including Farm Bureau members, community members and students. Below is the format last year's forum followed. The 2013 forum will be conducted in a similar manner:

- Welcome 6:00pm

- 25 minutes: Overview of Water Regulation History by Danny Merkley

- 25 minutes: Water Board Perspective by Lisa McCann

- 10 minute: Break

- 25 minutes: Farmer Perspective by Bruce Scott

- 15 minutes: Open Discussion by the Guest Speakers

- Questions from the Audience

- Closing Comments to end at 8:30pm

Would you be willing to join the forum as a panelist? Do you have any recommendations for other panelists to ask?

I look forward to hearing back from you. Until then, thank you for your time and consideration. Attached is the flier promoting the 2012 Water Forum as a reference.

Sincerely,

Whestes Steost

Megan Silcott

Brock Center for Agricultural Communications Director

msilcott@calpoly.edu

805.478.1510 


\section{Brock Center Forum Press Release 2013}

For further information contact:

Megan Silcott, Director

Brock Center for Agricultural Communication

One Grand Avenue

San Luis Obispo, CA 93407

Phone: 805.756.2892

Email: msilcott@calpoly.edu

Blog: brockcenter.wordpress.com

FOR IMMEDIATE RELEASE

Cal Poly's Brock Center for Agricultural Communication Hosts Forum Discussion on Meeting the Standards of Sustainable Produce and Dairy Policy

SAN LUIS OBISPO, C.A. Feb. 4, 2013-The Cal Poly Brock Center for Agricultural Communication will host an agricultural forum discussion with three panelists on February 27, 2013. The event takes place from 6:00-8:30 p.m. in the Cal Poly Pavilion, building six, room 128 and is open to the public. Panelists will discuss the implications of California sustainable agriculture policies, each from their own perspective. The panelists include sustainable agriculture award recipient Dino Giacomazzi, food safety consultant April Mackie and Honorable Dr. Sam Blakeslee.

The event will begin with a presentation of the impact of food safety policy in the produce industry by April Mackie. Mackie is a professional food safety and farm programs consultant. She has worked with Ocean Mist Farms and Martin Jefferson \& Sons. Mackie is the Vice Chair of Finance for the Monterey County Farm Bureau.

Mr. Dino Giacomazzi will then discuss food safety's role in sustainable agriculture. Giacomazzi is the fourth generation to manage his family's dairy farm founded in 1893. Giacomazzi was the 2012 Leopold Conservation Award recipient for California. He writes the Tech Talk column for Dairy Today Magazine and his personal blog, which states he is "saving the world one cow pie at a time" can be found at: www.dinogiacomazzi.com.

Honorable Dr. Sam Blakeslee will present about the responsibility of legislation in agriculture. Blakeslee is the former Republican California State Senator representing California's 15th State Senate district. He previously served as a California State Assemblyman from California's 33rd State Assembly district, and as former State Assembly Republican Leader.

The forum will conclude with an open discussion between audience and panel members. The mission of the Brock Center for Agricultural Communication is to create a bridge of communication between the agricultural industry, the media and the public. More information about the Brock Center and the upcoming forum can be found at: hitto://brockscenter.wordoress.com. 


\section{Announcing the Brock Center Water Forum Wed, February 29th, 2012 6-8pm, Pavilion 06-128, Cal Poly}

\section{Topic: A forum discussion about Region 3 water regulations,} the Ag Waiver, and impacts on the Central Coast

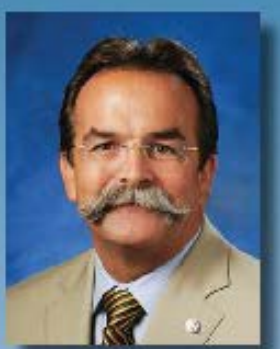

Guest Speaker: Danny Merkley Director, Water Resources California Farm Bureau Federation

Danny Merkley joined the California Farm Bureau Federation as director of water resources in December 2007. He represents Farm Bureau before the state Legislature and regulatory agencies on policy issues related to water development and water quality. Danny grew up and worked on the family farm in Solano and Yolo counties and is currently a member of the Yolo County Farm Bureau.

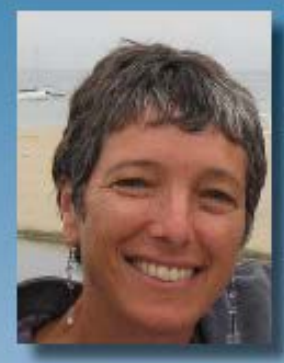

Guest Speaker: Lisa McCann Central Coast Regional Water Quality Control Board

Lisa McCann is an Environmental Program Manager at the Central Coast Water Board and she manages the Watershed Protection and Planning Section. She began working for the Board in 1995 and her section indudes the Agricultural Regulatory Program, Stormwater Management, and several others.

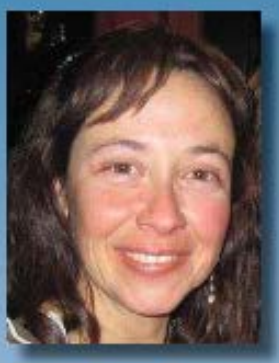

Contributor: Monica Barricarte Central Coast Regional Water Quality Control Board

Monica Barricarte has been working for the Central Coast Water Board since 2008. She has been a member of Sustainability in Practice and is a Certified Crop Advisor. She is an Agricultural Irrigation Specialist and a Drip-Micro Irrigation Designer and member of the Irrigation Association Ambassadors Program.
To learn more about the guest speakers and the Water Forum, scan above:

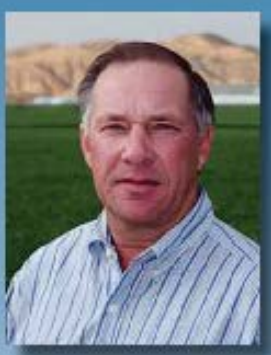

Guest Speaker: Bruce Scott Scott Brothers Dairy Farms WRCAC, Chairman

Bruce Scott is the Chairman of Western Riverside County Agriculture Coalition (WRCAC) and helps operate Scott Brothers Dairy Farms. Southern California has been home to Scott Brothers dairy and farming business for four generations. They're committed to agriculture sustainability and are proactive in working towards solutions to the issues facing agriculture. 


\section{Announcing the Brock Center Forum} Wed, February 27 th, 2013 6-8:30pm, Pavilion 06-128, Cal Poly

Topic: A forum discussion about California Agriculture and meeting the standards of Sustainable Produce and Dairy Policy.

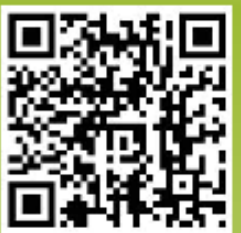

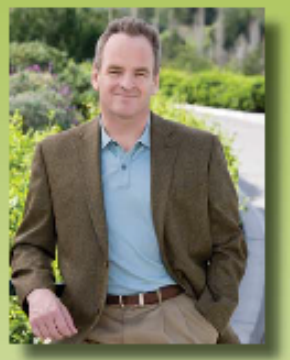

Guest Speaker: Honorable Dr. Sam Blakeslee Director, Cal Poly Institute for Advanced Technology or Public Policy

Former California State Senator Sam Blakeslee brings his unique background and perspective as the Legislature's only trained scientist, former Assembly Minority Leader and member of the Big 5, and a reputation as one of Sacramento's most bipartisan legislators to his new role as Founder and Director of the Cal Poly Institute for Advanced Technology and Public Policy. A research geophysist by training, Blakeslee has applied his background as a scientist to advance policies addressing energy-independence, long-range energy planning and resource conservation.

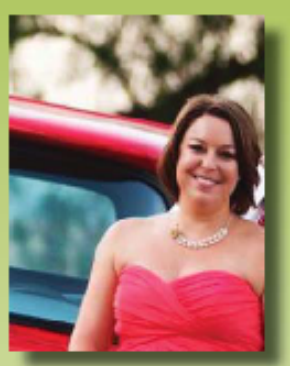

Guest Speaker: April Mackie Food Safety and Ag Issues Consultant

April Mackie is a professional food safety, water quality, environmental sustainability, and ag issues consultant. She has worked with large growershippers such as Ocean Mist Farms as well as direct growers like Martin Jefferson \& Sons. April is the Vice Chair of Finance for the Monterey Co. Farm Bureau. She serves as the Salinas Valley Calif. Women for Ag. president-elect and the past CWA Central Coast District Director. She is the immediate past president of Ag Against Hunger and the current Vice Chair for the Calif. Young Farmers and Ranchers. April and her husband, Todd were elected as the Western Region reps for the National YF\&R Committee. She graduated from Cal Poly, San Luis Obispo.
To learn more about the guest. speakers and the upcoming forum, scan above.

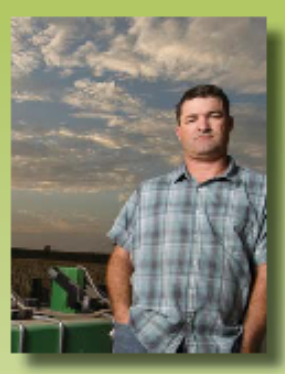

Guest Speaker: Dino Giacomazzi Giacomazzi Dairy 2012 Leopold Conservation Award

Dino Giacomazzi is the 4th generation to manage his family's dairy farm founded in 1893. The dairy operation consists of 950 milking cows and 900 acres of cropland that provides corn silage, wheat silage, and alfalfa for the cows. Dino was the 2012 Leopold Conservation Award recipient for California. Dino is a dairy advocate, social media proponent and technology coach. He writes the Tech Talk column for Dairy Today Magazine. His personal blog which states he is "saving the world one cow pie at a time" can be found at www.dinogiacomazzi.com.

Hosted by the Brock Center for Agricultural Communication 


\section{Ag Circle Maintenance}

\section{Background}

Published three times a year by the Brock Center for Agricultural Communication, Ag Circle magazine is produced by students and 1,500 copies are distributed each printing. The Brock Associates manage volunteer writers. Writers are guided through story ideas, angles, interviewing skills, writing feature and technical pieces and producing a professional quality story. The Brock Associates and writers are responsible for photography, content, design and layout of the magazine.

\section{Readership}

Copies of the Ag Circle magazine are mailed to every high school in California with an agriculture program, each California county Farm Bureau office, each California community college with an agriculture course, and distributed across Cal Poly's campus. 1,500 copies are shared each printing.

\section{Advertising Opportunities}

While the magazine's goal is to provide students with a real-world publication experience from start to finish, printing costs are taken into consideration. Students are asked to develop advertisements throughout the publication to offset printing and mailing expenses.

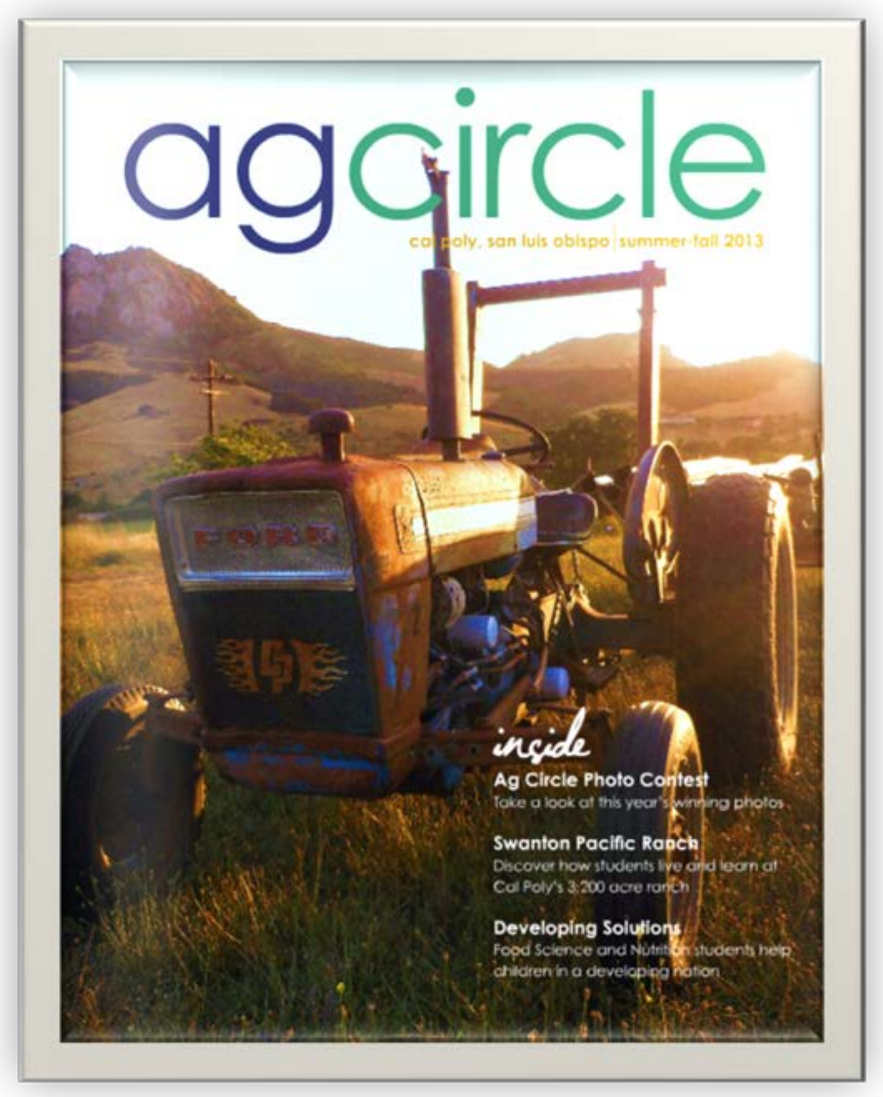

Figure 8: Ag Circle Summer-Fall 2013 


\section{Steps to Ag Circle Production}

1. Associates plan backwards from desired delivery of the final product in order to develop due dates for the various steps.

2. Associates brainstorm feature story ideas.

3. Assign writers, associate "coach" for each writer.

4. Provide writers with story angle, due dates, tips sheet and writing/photography needs for the particular story.

5. Associates guide with interviewing appointments, photography locations, dates, etc.

6. Contact printing company to keep them abreast of the project specifications, dates and needs.

7. Associates contact potential advertisers and secure artwork, design needs and payment.

8. Due dates are broken down to allow writers and associates ample editing and meeting time. Graphic design can begin immediately with layout and concepts.

9. One hard copy proof from the printer will be free of charge. The second proof is usually done electronically and submitted for final printing.

10. Proofing should be for all aspects: fonts, text similarity, photo clarity and placement, bleeds, advertisements, story widows and orphans, page numbers, spelling and grammar.

11. Do not go to print until the team is satisfied with their work.

\section{Printing Expenses for Ag Circle with PRP Co. in San Luis Obispo, CA.}

\begin{tabular}{|c|c|c|c|}
\hline Expenses & Description & & \\
\hline $\begin{array}{l}\text { Labor (4 staff } \\
\text { members) }\end{array}$ & $\begin{array}{l}1 \text { Editor, } 3 \text { Brock Associates, } 10 \text { weeks of work paid through } \\
\text { endowment funding }\end{array}$ & $\$$ & $3,600.00$ \\
\hline Printing \& Finishing & 1,500 copies, full color, 32 pages, 80 lb gloss text: $\$ 1.84$ per unit & $\$$ & $2,760.00$ \\
\hline Mailing Service & Third Party mailing service through printer & $\$$ & 125.06 \\
\hline \multirow[t]{2}{*}{ Postage (450 pieces) } & $\begin{array}{l}\text { Non-profit mailing utilized through University, single pieces } \\
\text { mailed at } \$ 1.52 \text { for rural addresses }\end{array}$ & $\$$ & 166.81 \\
\hline & Total Cost per Quarterly Printing of Ag Circle & $\$$ & $6,651.87$ \\
\hline
\end{tabular}

Income Item
\begin{tabular}{|l|l|c|}
\hline Partner & Description & \\
Advertisements & Industry support & $\$ 1,150.00$ \\
\hline & Total Income & $\$ 1,150.00$ \\
\hline \hline
\end{tabular}

The Mary and Jim Brock Endowment for Agricultural

Net Communication covers remaining expenses

$\$ \quad(5,501.87)$ 
A Few Tips

\section{Writing for agcircle Winter 2013 Issue}

1. Interviewing Sources

- Introduce yourself and agcircle magazine.

- Write out questions you plan on asking (about ten).

- Ask open-ended questions. No yes/no questions. Good example: "Can tell me about xyz...?"

- Ask follow-up questions to gather more details.

- Use a tape recorder to make sure you get lots of good quotes. You need to first ask your source if it's okay to use one.

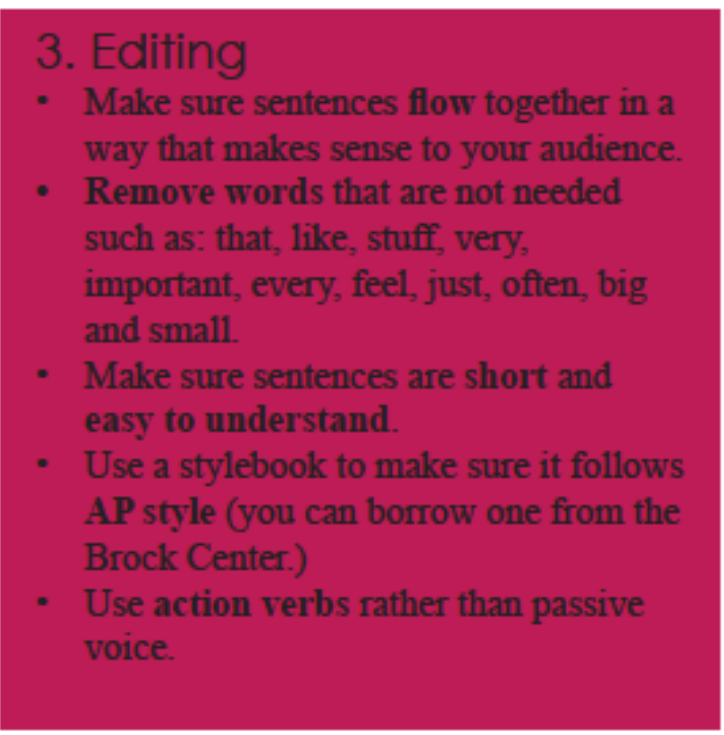

\section{Writing}

- Write the entire article before you start editing and getting picky.

- Start with the most interesting part of your story (the lead).

- Consider following your lead with a strong quote and then explain the main idea of your story.

- Use transitions when moving from one topic to another.

- Consider your audience: Cal Poly students, high school ag programs, alumni and other industry professionals.

\section{Some notes on quotes:}

- Be sure to introduce persons quoted. Example: Megan Silcott is the Director of the Brock Center for Agricultural Communications.

- Write quotes like this: "The Brock Center is awesome," Silcott said.

- Be sure to record quotes exactly as they were stated.

- Spread out interesting quotes throughout the article to keep readers' attention.
Start now!

Don't wait till the last minute! Ask Brock Associates for help!
Stories and photos are due by October 28 Email them to: cp.agcircle@gmail.com Or stop by the Brock Center (10-234) 
Ag Circle Advertising Rate Sheet

\section{READERSHIP}

- 53 California Farm Bureau county offices

- $350+$ High School agriculture departments statewide

- Cal Poly College of Agriculture, Food and Environmental Sciences

\section{GRAPHICS}

- Submit ad resolution greater than 300 dpi

- No web compressed images

- Submit as JPEG, PSD, PDF or TIFF

- CMYK color mode

- Full bleed

\section{PRICES}

- $\$ 150$ half page color $8.5^{\prime \prime} \times 5.5^{\prime \prime}$

- \$275 full page color $8.5^{\prime \prime} \times 11^{\prime \prime}$

- $\$ 350$ inside back cover $8.5^{\prime \prime} \times 11^{\prime \prime}$

- $\$ 50$ ad design

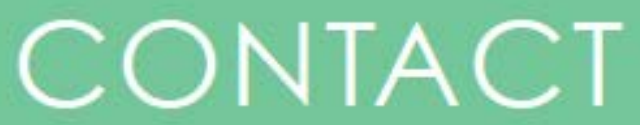

Brock Center for Agricultural

Communication

brockctr@calpoly.edu

1 Grand Avenue

San Luis Obispo, CA 93407 


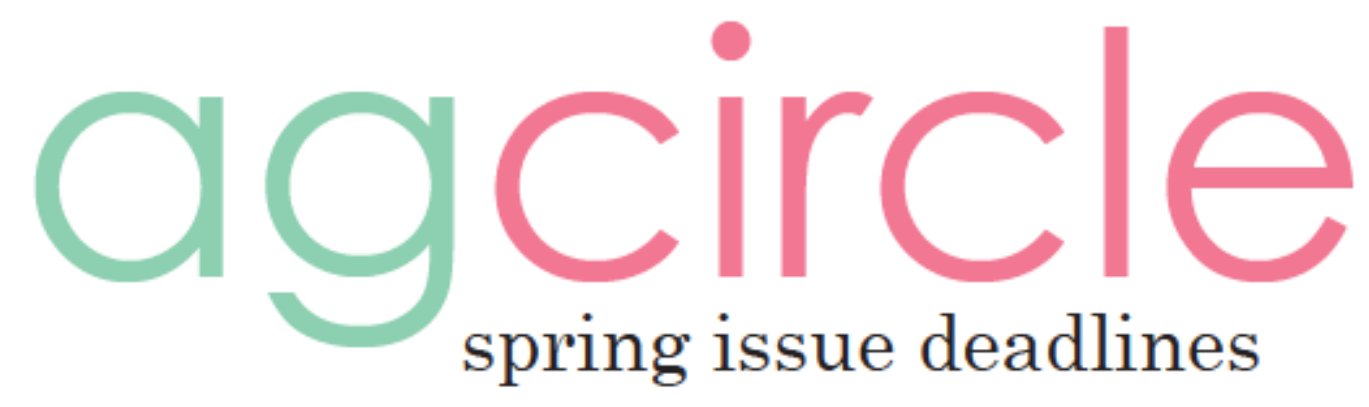

Submissions Fri. Jan. 24

First Draft Edits Mon. Feb. 3

Final Draft Edits Fri. Feb. 7

Graphic Design Wed. Feb. 12

First draft to PRP Mon. Feb. 17

Paper Proof Mon. Feb. 24

Due to Printer Wed. Mar. 5

Out to Readers Mon. Mar. 10

"Goals are dreams with deadlines."

-Diana Scharf Hunt, American Author and Time-Management Guru 
Ag Circle Critique from the winning Spring 2012 Issue

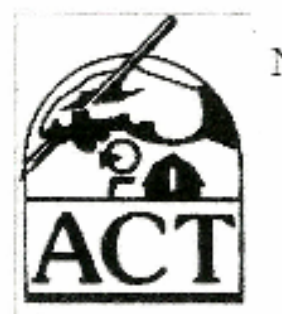

National Agricultural Communicators of Tomorrow

\section{Critique \& Contest}

\section{Publication Division}

\section{Magazincs}

1st Pasc - Ag Circle, Sprriag 2012 - Joues, Fricud, Issacson, Ray

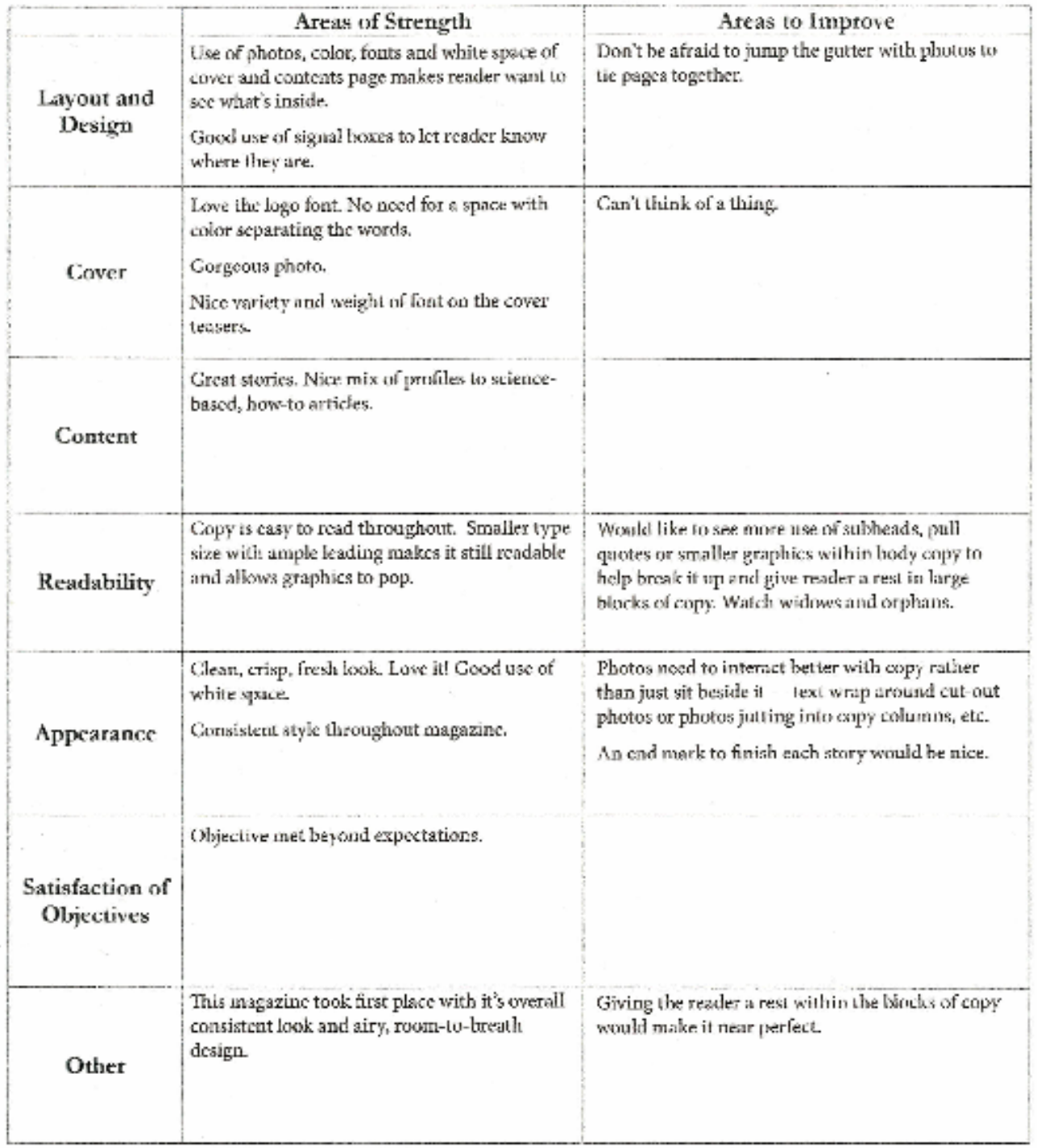




\section{Community and Education Projects}

\section{Public Service Announcement Samples}

Two-minute PSA Resource Conservation Districts

Did you know there are over 90 Resource Conservation Districts throughout California? Each district covers a different geographic territory by county. You might wonder how the conservation districts came to be. In the early 1930s, dustbowl conditions were caused as millions of acres of cropland experienced drought and attendant soil loss. Farmers and ranchers of the 1930s did not have access to information and modern practices to help them manage natural resources.

In response to the dire agricultural need, the United States Congress established the Soil Conservation Service in 1937 to work with farmers and ranchers and ensure our future doesn't include another dustbowl.

Wanting a local perspective to soil and conservation solutions, communities led the way to the development of community-based Resource Conservation Districts, which are governed by you, local landowners. Organizing in smaller, local regions gives a grassroots voice to the Unites States Department of Agriculture through the updated program called Natural Resource Conservation Service or the NRCS.

The California Association of Resource Conservation Districts is in partnership with the California Department of Conservation, the California Organization of District Employees and the NRCS.

Resource Conservation Districts, known as RCDs, are the states' only grassroots conservation delivery system that identifies our local problems and guides solutions on a voluntary basis. Working collectively on the state level, grants our local RCDs more resources when working independently in local regions to address and change roadblocks.

The core mission of all RCDs is to promote the conservation of California's natural resources. RCDs advise and educate our communities about land stewardship ethics and sustainability. And guess what? RCDs provide free or discounted technical assistance and field advice to property owners.

RCDs can provide you with wildlife habitat enhancement and restoration projects, invasive species management, watershed restoration, permits and planning guidance. You can learn more by finding your community RCD online at www.carcd.org

\section{0-second PSA Resource Conservation Districts}

Did you know there are over 90 Resource Conservation Districts throughout California? Each district covers a different geographic territory by county. 
Resource Conservation Districts, known as RCDs, are the states' only grassroots conservation delivery system that identifies local water and soil problems and guides solutions on a voluntary basis.

RCDs advise and educate our communities about land stewardship ethics and sustainability. And guess what? RCDs provide free or discounted technical assistance and field advice to property owners.

From watershed management to permits and conservation planning, you can learn more by finding your community RCD online at www.carcd.org 


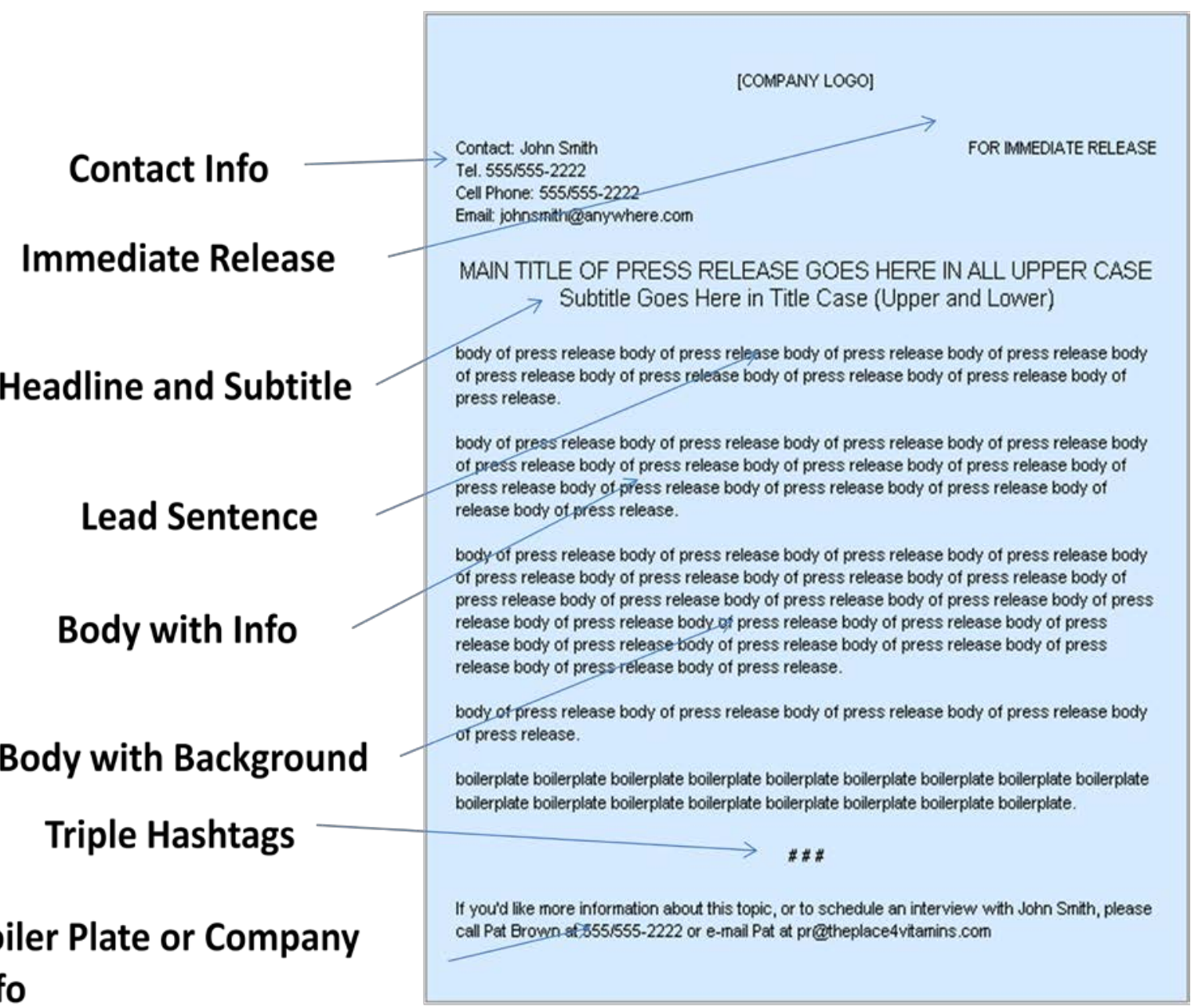



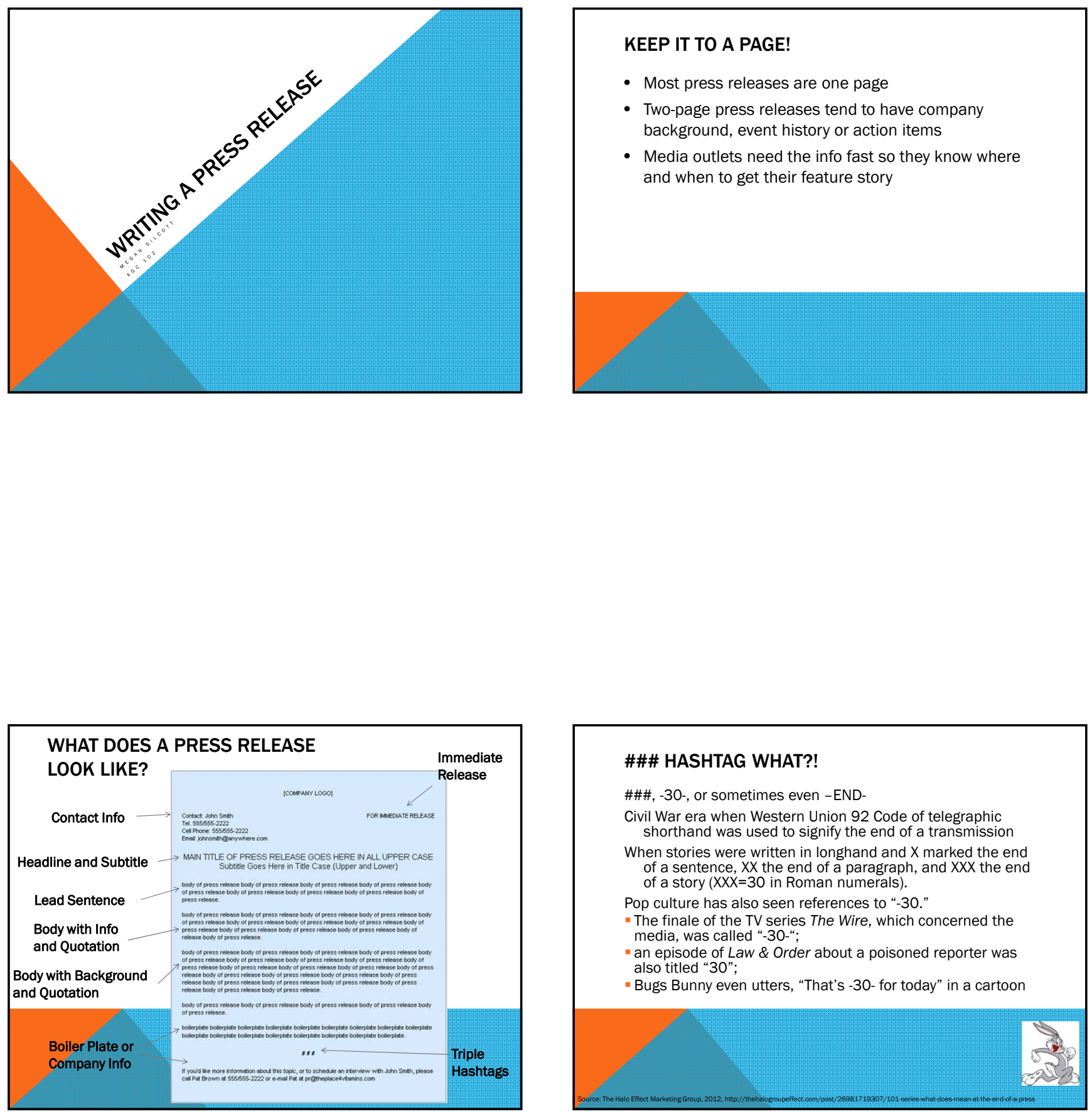

\section{\#\#\# HASHTAG WHAT?!}

\#\#\#, -30-, or sometimes even -END-

Civil War era when Western Union 92 Code of telegraphic shorthand was used to signify the end of a transmission

When stories were written in longhand and $X$ marked the end of a sentence, $X X$ the end of a paragraph, and XXX the end of a story (XXX=30 in Roman numerals).

Pop culture has also seen references to "-30."

"The finale of the TV series The Wire, which concerned the media, was called "-30-“;

- an episode of Law \& Order about a poisoned reporter was also titled "30";

" Bugs Bunny even utters, “That's -30-for today" in a cartoon

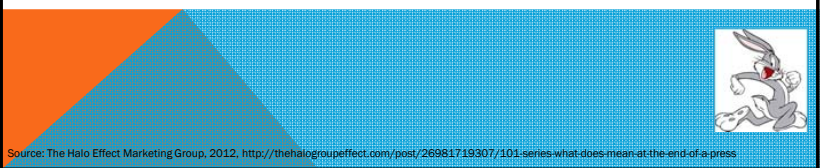




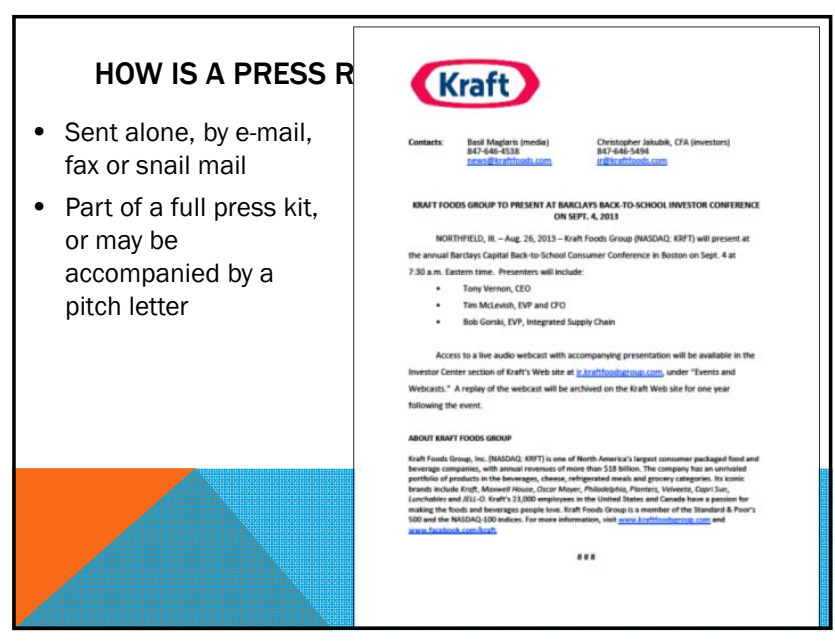

\section{HEADLINE TIME}

State your most exciting news, finding or announcement in as few words as possible. Emulate the headlines you see in the newspaper every day.

- Poor Press Release Headline: Farmer Bill Dies in House

- Strong Press Release Headline: Pesticides, fungicides harming bee colonies, UM study says

\section{"BEFORE YOU WRITE A WORD, REMEMBER THIS:}

The reporter isn't interested in helping you make money or driving visitors to your site. He's looking for a story that will be interesting to his readers and pleasing to his editor.

He could care less about your great selection, super customer service and commitment to quality. He wants to know only the info that will help him craft a good story about teens and their weight.

Take your ego out of it. Take your natural inclination to sell, sell, sell out of it. Look at your story with a cold, objective eye."

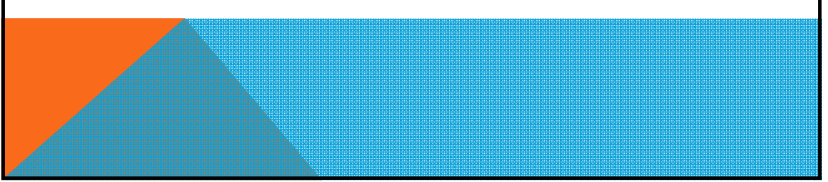

\section{SUBHEAD}

The press release subhead gives you the opportunity to flesh out your angle and further hook the reporter, without stepping on the drama of the press release headline.

Example:

John Deere Rolls Out More Powerful 8R Series Tractors with FT4 Engines

New $8 R$ tractors range from $245-370 \mathrm{hp}$ with more comfort, control \& integrated technology.

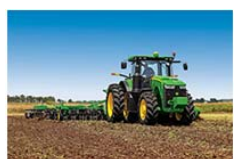

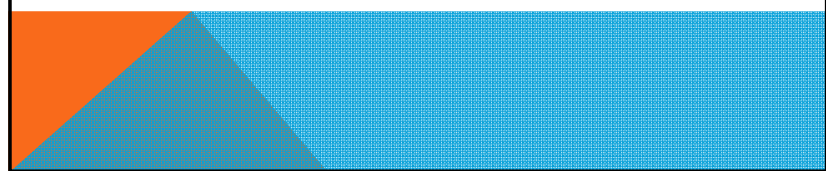




\section{THE PRESS RELEASE LEAD}

Lead paragraph includes the who, what, when, where and how of the story.

"There's no room for BS, hype or sell. Just the facts."

Since its launch at World Ag Expo in February of 2012, the Ag Warriors program has assisted veterans in search of careers in the agriculture industry. The program, which has provided veterans with training and career building

program, which has provided veterans with training and career buliding
resources, will be continued by AgCareers.com, the leading online career site and human resource service provider for agriculture, food, natural resources and biotechnology.

Source: http:///www.worddagexpo.com/intemationalagricenter-and-agcareers com-partnerto-help.vetetrans

\section{STRONG QUOTES VALIDATE INFORMATION}

"AgCareers.com is honored to be chosen to continue the efforts of the International Agri-Center's Ag Warriors program," said Eric Spell, president of AgCareers.com. "We are excited to open the door for both employers and veterans to connect regarding employment and careers within the agribusiness and food industries through AgCareers.com. We view the program as a way to honor veterans' service and assist them in taking the next steps to career success."

\section{THE PRESS RELEASE LEAD}

Good:

America's teenagers are angry at Hollywood for glamorizing ultra-thin bodies, and many girls say they feel too selfconscious about their bodies as a result of watching TV, movies and music videos. The findings are gleaned from more than six months of ongoing discussion and debate at the website theplace4vitamins.com. According to Theplace4vitamins.com President John Smith, anger and resentment toward the Hollywood ultra-thin runs deep, particularly among teenage girls.

\section{THE REST OF THE PRESS RELEASE}

- Back up whatever claims were made in the lead and headline

- Use enough supporting material to make your case, and to demonstrate that, whatever angle you're promoting, it wasn't something you slapped together carelessly.

- A quote will help the desired perspective

- Or, you might ask an expert in that industry for a quote about the subject or event's purpose

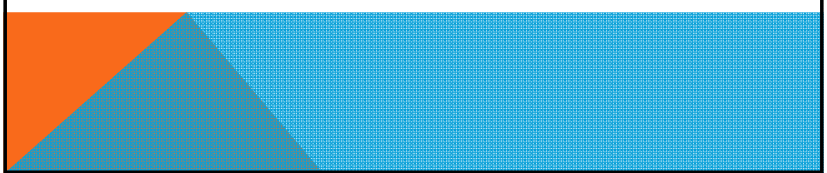




\section{THE BOILER WHAT?}

Finally, spend a sentence or two describing your company, club and they/it/you do

"boilerplate" - an old newspaper term meaning a block of standard text that's used over and over again

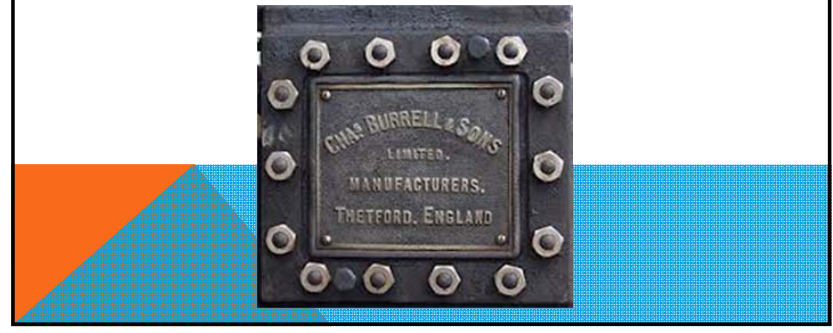

\section{WIRE SERVICES}

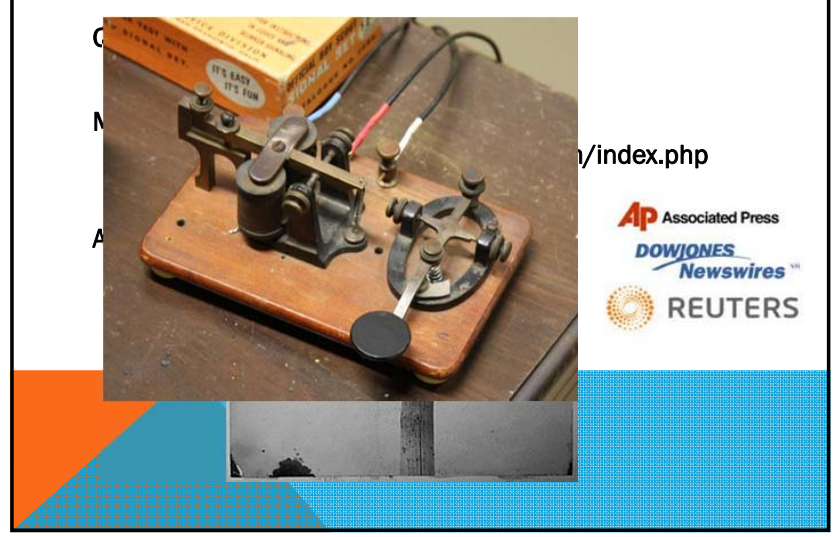

\section{A FEW LAST WORDS}

- One more trick: below the \#\#\#'s, add a line that says something like:

- If you'd like more information about this topic, or to schedule an interview with John Smith, please call Pat Brown at 555/555-2222 or e-mail Pat at pr@theplace4vitamins.com

- Stay away from hype-bloated phrases like "breakthrough", "unique", "state-ofthe-art", etc.

- Always write it from a journalist's perspective. Never use "I" or "we" unless it's in a quote.

- Read acclaimed newspaper writing, such as the New York Times or the Washington Post to get a feel for the style.

- Shorter is better. If you can say it in two pages, great. If you can say it in one page, better.

\section{FOR MORE HELP}

Visit www.publicityinside.com 


\section{Sample Media Calendar Plan}

\section{Annual Press Release and Community Calendar Planning}

\begin{tabular}{|l|l|l|}
\hline \multicolumn{1}{|c|}{ January Events } & February Events & March Events \\
\hline Judging Teams & FFA Week & Parli Pro Win \\
\hline & & \\
\hline & & \\
\hline & & \\
\hline & & \\
\hline
\end{tabular}

\begin{tabular}{|c|l|c|}
\hline April Events & May Events & June Events \\
\hline State FFA Conference & Awards Night & Summer BBQ Fundraiser \\
\hline & & \\
\hline & & \\
\hline & & \\
\hline & & \\
\hline
\end{tabular}

\begin{tabular}{|c|l|r|}
\hline \multicolumn{1}{|c|}{ July Events } & August Events & September Events \\
\hline County Fair Auction & Officer Retreat & Open House Plant Sale \\
\hline & & \\
\hline & & \\
\hline & & \\
\hline & & \\
\hline
\end{tabular}

\begin{tabular}{|c|l|l|}
\hline October Events & November Events & December Events \\
\hline Greenhand Initiation & Canned Food Drive & Christmas Parade \\
\hline & & \\
\hline & & \\
\hline & & \\
\hline & & \\
\hline
\end{tabular}

Event Ideas:

- Officers recognized at Chapter Officer Leadership Conference

- Vice Principal or Counselor attends State Conference

- Drive-thru BBQ this Sunday

- Plant Sale starting Friday

- Cotton Judging Team places $2^{\text {nd }}$ at State Competition

- Spanish Creed Speaker wins Section

- FFA President Earns top Honors of College Scholarship

- Boosters elects new leadership 


\title{
Sample FFA Press Release Template
}

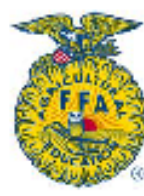

\section{FOR IMMEDIATE RELEASE}

CONTACT

Advisor or Reporter Name

Chapter Name

High School Name

Chapter Reporter or Advisor email

888-332-2589

\section{FFA DAY AT THE PITTSBURGH PIRATES}

INDIANAPOLIS (Monday, June 10, 2013/National FFA Organization) - FFA members and supporters can take advantage of special discount ticket prices and an exclusive merchandise offer for showing their support of FFA by attending FFA Day at the Ballpark with the Pittsburgh Pirates on Sunday, June 30.

The Pirates take on the Milwaukee Brewers at 1:35 pm at PNC Park in Pittsburgh.

The Pirates organization is offering FFA members, their families and friends, alumni and FFA supporters two ticket specials for helping raise awareness about FFA at the game. Fans can choose either an Outfield Box Seat ticket for $\$ 25$ and receive a free replica Roberto Clemente Pirates jersey or a Grandstand Ticket for $\$ 18$ and receive a free replica Pirates team hat.

To order a ticket for FFA Day at the Ballpark with the Pittsburgh Pirates, FFA members and supports should visit www.Pirates.com/FFA and use coupon code "FFA" to order tickets online.

FFA chapters that would like to attend the game as a group and buy 15 or more tickets together should contact Elliott Crichfield at (412) 325-4930 or by email at Elliott.Crichfield@Pirates.com.

The National FFA Organization's official mascot, Flyte the Owl, will entertain FFA and Pirates fans inside and outside PNC Park before, during and after the game.

This summer, the National FFA Organization has partnered with four Major League Baseball teams including the Pirates - for FFA Day at the Ballpark events. For more, visit www.FFA.org/MLB.

The National FFA Organization provides leadership, personal growth and career success training through agricultural education to 557,318 student members in grades seven through 12 who belong to one of 7,498 local FFA chapters throughout the U.S., Puerto Rico and the Virgin Islands.

\begin{abstract}
About National FFA Organization
The National FFA Organization is a national youth organization of 557,318 student members as part of 7,498 local FFA chapters in all 50 states, Puerto Rico and the Virgin Islands. The FFA mission is to make a positive difference in the lives of students by developing their potential for premier leadership, personal growth and career success through agricultural education. The National FFA Organization operates under a federal charter granted by the 81 st United States Congress and it is an integral part of public instruction in agriculture. The U.S. Department of Education provides leadership and helps set direction for FFA as a service to state and local agricultural education programs. For more, visit the National FFA Organization online at www FFA_org, on Facebook, Twitter and the official National FFA Organization blog.
\end{abstract}




\section{Brock Center Quarterly Reports from 2011-2013}

\section{Fall Quarter 2011 Report}

Date: December 2, 2012

To: $\quad$ Dr. David Wehner, Dean CAFES

Dr. Bill Kellogg, Department Head

From: Megan Silcott, Director

Leslie Friend, Carrie Isaacson, David Jones and Jennifer Ray, Brock Center Associates

We are pleased to provide you this quarterly report that reflects the activities of the Brock Center. Needless to say, we had a very busy quarter.

1. Water Forum:

a. Winter Water Forum planned for Wednesday, February 29 from 6:00-8:00 p.m. to be hosted by Brock Center in the Pavilion near PAC

b. Industry and Campus Contacts:

i. Jean-Pierre Wolff: Recommended to start on the local and county scale then open the forum up to the broader view of State Water Board workshops and listening sessions that are planned and will most likely turn into legislation.

ii. Jackie Crabb and Joy Fitzhugh met with Megan Silcott at the Farm Bureau office to provide their forum input and speaker recommendations. They mentioned too broad of a forum will lead to some confusion and the panel needs to be well-balanced

iii. Jeff Reimer from Cal Poly met with Megan Silcott and suggested Dr. Brian Dietterick, IRTC, Tryg Lundquist and Kim Busby be contacted as potential forum contributors with campus perspectives.

iv. Kevin Piper and Aaron Lazanoff recommended an evening gathering, 6:00-8:00 p.m. with a break in the middle as a transition to new topics.

2. Fall Issue of Ag Circle

a. The Brock Associates set specific due dates for various stages of magazine production and delegated the writing assignments to a large group of student writers.

b. This quarter represents the first time an issue has been produced in a quarter and will be delivered to the campus community during the same quarter as the issue was prepared.

c. Mark Looker professionally edited the Fall $2011 \mathrm{Ag}$ Circle issue and the issue was submitted to Branch Smith Printing in Dallas, Texas on November 21 and should arrive to campus by December 5 .

3. Open House 2012

a. Meeting with Ellen Cohune, Dr. Bill Kellogg, David Jones and Megan Silcott to discuss the Open House magazine and Brock's role in developing Open House.

b. Additional meetings planned with Ellen Cohune to prepare the magazine content.

c. Committee participation fliers went up around Building 10 and 11 in late 
November. An additional Open House magazine meeting will be rescheduled with Ellen Cohune.

4. Brock Website and Social Media

a. The Brock website will be updated to make it current and then new design work will begin over winter break.

b. Ag Circle now has a Twitter account with 110 followers, the Brock Center has a Facebook page with 318 followers, and Ag Circle has a Facebook page with 591 followers. An example of using social media tools is visually showing with photo postings, the students working in the center and asking for addresses to send magazines through the mail.

5. Brock Equipment and Resource Updates

a. An iPad was purchased in October 2011 to launch student portfolios, videos, and social media. The iPad will be used to showcase the students' ability to use new technology and provide portfolios at conferences to industry contacts.

b. A new iMac was purchased in November 2011 to replace an 8-year-old system.

c. Adobe CS 5.5 was downloaded to all Brock Computers to keep the students up to speed with software advancements.

d. Two new Photoshop and design books were purchased to provide training modules and modern design how tips.

e. Digital cameras and video equipment are available for students to use on various projects.

f. Megan Silcott attended a grant writing workshop with other nationally recognized Agricultural Communication programs in Dallas, Texas. The other universities were pleased to know Cal Poly and Brock Center can help them distribute research materials in California, and lend a hand to their efforts in education.

6. Fall/Winter Projects

a. Fall issue of Ag Circle

b. One-page brochure for Agricultural Communication students to learn about career opportunities

c. Winter issue of Ag Circle plans

d. Website updates, blog initiation

e. Spring issue of Ag Circle plans

7. Future Goals

a. Update website design and add a blog

b. Develop a photo workshop with alumni support to offer students

c. Utilize the Journalism Department for broadcasting experience

d. Develop an advertising relationship with Mustang Daily staff to create income for Ag Circle

e. Host another forum in Spring; possibly a topic of telling your agriculture story to consumers 
8. Next Meeting: Jan, 5, 2012, 11:00 a.m. in the Brock Center

Respectfully submitted, Megan A. Silcott

Megan Silcott

Brock Center Director

msilcott@calpoly.edu

805.756.2892 


\section{Winter Quarter 2012 Report}

Date: March 21, 2012

To: Dr. David Wehner, Dean CAFES

Dr. Bill Kellogg, Department Head

From: Megan Silcott, Director

Leslie Friend, Carrie Isaacson, David Jones and Jennifer Ray, Brock Center Associates

We are pleased to provide you this quarterly report reflecting Brock Center activities.

1. Water Forum:

a. Winter Water Forum was successfully executed on Wednesday, February 29 from 6:00-8:00 p.m. in the PAC Pavilion.

b. The topic covered Region 3: the history of CA water regulation, how regulations are needed for monitoring and can challenge the agriculture industry.

c. Speakers included: Bruce Scott of Scott Brothers Dairy Farms, Lisa McCann of the Central Coast Regional Water Quality Control Board, and Danny Merkley of the California Farm Bureau Federation.

d. Attendance:

i. 89 people signed in from Cal Poly and various community organizations

ii. Close to 150 people were present

iii. 2 people came from Nevada to learn about CA's water regulations

iv. CAFES Dean Wehner attended the event in support of the Brock Center.

e. Facility

i. Building 6, Room 128 proved to be a good location for the event with convenient parking accessibility and a pleasant atmosphere. The charges were $\$ 381.50$ for the facility services, which they added in a stage riser for the speakers at the last minute on our behalf.

ii. Campus Catering provided light appetizers that were well received: $\$ 340.79$

2. Spring Issue of Ag Circle

a. The Brock Associates set specific due dates for various stages of magazine production and delegated the writing assignments to a large group of students.

b. Ellen Cohune and Donetta Rosson aided the Brock Center with the editing process during Winter Quarter.

c. Two half-page ads were purchased by local businesses: JB Dewar and Horsepower. Morgan Dewar, AGC major, designed the ad for her family’s business.

d. PSPrint.com was used as the printer and came recommended by Mr. Paul Bittick at Mustang Daily.

e. 500 extra magazines (totaling 1,500) were ordered this issue in efforts to share more magazines across campus, outside of CAFES, in addition to the high schools and county Farm Bureau offices.

f. Spring 2012 issue will be on campus during the week of March 26 meaning the Brock Center has produced two issues within six months. 
3. Open House 2012 Magazine

a. Carrie Isaacson is the editor for the renamed Open House magazine:

PolyCulture. Carrie has met with Ellen Cohune and Megan Silcott several times to update everyone on the magazine's progress.

b. Carrie and Ellen meet periodically with the writers to ensure their pieces are staying on track with development and deadlines.

c. David Jones is adding in design guidance and templates as requested by Ellen.

4. Brock Website and Social Media

a. The Brock website is being updated.

b. Ag Circle now has a Twitter account with 175 followers, an increase of 65 since Fall, the Brock Center has a Facebook page with 325 friends, an increase of seven since Fall, and Ag Circle has a Facebook page with 657 friends, an increase of 66 since Fall. An example of using social media tools is visually showing with photo postings, the students working in the center and asking for addresses to send magazines through the mail.

c. Winter Quarter began the Brock Center blog and has provided another outlet for students to engage with social media and add to their portfolio work. The blog was used to advertise the Water Forum and drove traffic to the site via a QR code from campus posters.

d. David Jones and Carrie Isaacson received national coverage during Winter Quarter as they documented and wrote about their “Going Vegan” for a week experience. Social media helped launch their popularity.

5. Brock Equipment and Resource Updates

a. A new keyboard was purchased to replace an older model.

b. The external hard drive helped save a copy of the Spring issue during a printing error.

6. Travels and Projects

a. CAFES History Project: Students enrolled in AGC 400 Special Problems have earned their credit in Winter Quarter for conducting video and voice recordings with those listed below.

\begin{tabular}{l}
\hline Gene Starkey \\
\hline Dick Johnson \\
Joe Sabol \\
\hline Lark Carter \\
Bob Cummings \\
Ron Regan \\
\hline Manfred Sander \\
\hline
\end{tabular}

i. Questions during the interviews range from: "What does Learn by Doing mean to you?" to "How has the university changed?" to "Tell us about your favorite trip with Cal Poly.”

ii. The students will continue contacting a growing list of legendary faculty 
members who helped shape the university and CAFES.

iii. The videos will be used to make a short film to be shown at Open House. More projects can be completed as students have time.

b. Mike Fontes of Cuesta College has offered the Brock Center a video project.

i. Four students will help film the Tractor Pull during Open House.

ii. The students will process and edit the video to include voiceovers, text and music to have the end project aired on Channel 19.

c. Summer/Fall issue of Ag Circle to be in readers' hands May 25

d. Applications were received and interviews were conducted by the Brock Associates and Megan Silcott for the 2012-2013 Brock Staff.

i. Taylor Pires, Amanda Meneses, and Mandy Brazil were chosen from a deep field of eight candidates.

ii. The candidates submitted their application, a personal statement and sample press release prior to the interview rounds.

e. Jennifer Ray, David Jones and Carrie Isaacson traveled to Lubbuck, Texas, in February for the Professional Development Conference held at Texas Tech University. The Brock Center covered a portion of their travel and meal expenses.

7. Future Goals

a. Update website design

b. Continue interviewing CAFES faculty legends

c. Expand the readership of Ag Circle

d. Develop a photo workshop with alumni support to offer students

e. Utilize the Journalism Department for broadcasting experience

f. Host another forum in Spring; possibly a topic of telling your agriculture story to consumers

Respectfully submitted, Megan A. Silcott

Megan Silcott

Brock Center Director

msilcott@calpoly.edu

805.756.2892 


\section{Spring Quarter 2012 Report}

Date: June 13, 2012

To: Dr. David Wehner, Dean CAFES

Dr. Bill Kellogg, Department Head

From: Megan Silcott, Director

Leslie Friend, Carrie Isaacson, David Jones and Jennifer Ray, Brock Center Associates

We are pleased to provide you this quarterly report reflecting Brock Center activities.

1. Open House Magazine

a. Maureen O'Conner, Megan Silcott and Ellen Cohune are working on developing an Open House Magazine guideline including due dates, responsibilities, advertisement and printing information.

2. Sharing Your Ag Story Forum: Monday, May 21, 2012

a. Matt Rush, Executive Vice President of the New Mexico Farm Bureau and fourth generation cattle rancher

b. The topic covered how easy it is to speak with industry supporters and important to share agriculture's message with people of all walks of life and interests as they may become industry champions with educated conversations about where their food comes from and how its grown.

c. Attendance:

i. 20 people signed in from Cal Poly and a couple from community

d. Facility

i. Building 14, Room 249 was a good sized room; however, the room was far from CAFES facilities on campus without parking nearby for easy access. The room was free of charge.

ii. Light hors d'oeuvres were provided by Brock Center for about $\$ 80$.

e. Recommendation: Do not host an event during week nine of Spring quarter. Attendance was very low possibly due to class projects due and the second round of midterms during that week. Consider hosting a speaker similar to Matt Rush as part of the Ag Education and Communication Banquet or hosting a local speaker to avoid traveling fees.

3. Summer-Fall Issue of Ag Circle

a. The Brock Associates set specific due dates for various stages of magazine production and delegated the writing assignments to a large group of student writers.

b. Ellen Cohune aided the Brock Center with the editing process during Spring Quarter.

c. Three half-page ads were purchased by local businesses: JB Dewar, Horsepower and Poor Richards Press. Morgan Dewar, AGC major, designed the ad for her family's business.

d. Poor Richards Press was used as the printer and decreased the cost of printing with a trade in advertising on the back cover. 
e. 1,500 magazines were ordered this issue in efforts to share more magazines across campus, outside of CAFES, in addition to the high schools, junior colleges with agriculture courses and county Farm Bureau offices.

f. The Summer-Fall 2012 issue was delivered on campus during the week of June 4 which is the fourth publication produced within three quarters by the Brock Center.

4. Brock Website and Social Media

a. The Brock website needs to be updated prior to Fall.

b. Ag Circle now has a Twitter account with 282 followers, an increase of 107 since Winter, the Brock Center has a Facebook page with 330 friends, an increase of five since Winter, and Ag Circle has a Facebook page with 735 friends, an increase of 78 since Winter.

c. The Brock Center blog on wordpress.com continues to be an outlet for students to share short stories, provide input and increase agriculture education with their words, photos and video entries.

5. Brock Equipment and Resource Updates

a. Suggested equipment purchases in the upcoming months: a new mouse trackpad for the double screen system, clipboards for sign-in sheets, have the video camera serviced, lighting equipment for video production and Lynda.com membership for training purposes.

6. Projects

a. CAFES History Project: Students enrolled in AGC 200 and 400 Special Problems have earned their credit in Fall, Winter and Spring Quarter for conducting video and voice recordings with those listed below.

\begin{tabular}{l}
\hline Gene Starkey \\
\hline Dick Johnson \\
\hline Joe Sabol \\
\hline Lark Carter \\
Bob Cummings \\
Ron Regan \\
Manfred Sander \\
Bob McCorkle \\
Mark Zohns \\
\hline Russ Anderson \\
\hline
\end{tabular}

i. Questions during the interviews range from: "What does Learn by Doing mean to you?" to "How has the university changed?" to "Tell us about your favorite trip with Cal Poly."

ii. The students will continue contacting a growing list of legendary faculty members who helped shape the university and CAFES.

iii. The videos will be used to make a short film to be shown at Open House. More projects can be completed as students have time. 
b. 2012-2013 Brock Staff

i. Taylor Pires, Amanda Meneses, and Mandy Brazil met with Jennifer Ray and Megan Silcott to begin training for their upcoming year. Planning and story assignments are already being distributed for summer break.

7. 2011-2012 Brock Center Assessments by Associates

a. Questionnaires (assessment questions attached to this report) were distributed and collected during Spring Quarter.

b. Note-worthy comments:

i. Purchase Flip or similar cameras for easy video interviews and blogging.

ii. Obtain tutorials and tip resources for Adobe Creative Suite.

iii. Consider limiting visitors/office space to only editors; especially during deadlines.

iv. Include all editors during the printing process so they better understand printing requirements and costs.

v. Editors received adequate pay for their time.

vi. iPad made social media updates easy to improve communications.

vii. Continue weekly meeting agendas to make meetings more productive.

viii. Keep a positive reputation with the writers and keep up the agriculture issues stories.

ix. Submit stories to Mustang Daily.

x. Maintain quality of design and stories as the 2011-2012 team!

8. Future Goals

a. Update website design

b. Continue interviewing CAFES faculty legends

c. Expand the readership of $\mathrm{Ag}$ Circle while increasing advertising to offset printing costs

d. Develop a photo workshop with alumni support to offer students

e. Utilize the Journalism Department for broadcasting experience

f. Host a training forum in Fall; a survey of forum participants showed students are willing to pay a small fee to be trained in the Adobe Creative Suite.

Respectfully submitted, Megan A. Silcott

Megan Silcott

Brock Center Director

msilcott@calpoly.edu

805.756.2892 


\section{Fall Quarter 2012 Report}

Date: December 20, 2012

To: Dr. David Wehner, Dean CAFES

Dr. Bill Kellogg, Department Head

From: Megan Silcott, Director

Jennifer Ray, Mandy Brazil, Amanda Meneses and Taylor Pires, Brock Center

Associates

We are pleased to provide you this quarterly report reflecting Brock Center activities.

1. Open House Magazine

a. Maureen O’Conner, Jennifer Ray, Megan Silcott and Ellen Cohune met to review the improvements, changes, needs and content of the Open House magazine for April 2013. Maureen will provide a mini sales training session for Peter Delle, Advertising Manager and his team as it develops.

2. Plans for the 2013 Community Forum

a. Scheduled for Wednesday, February 27 from 6:00-8:30 p.m. in the PAC Pavilion.

b. Topic: Food Policy and its implications on California Agriculture

c. Panelists: April Mackie, Cal Poly alumni and Food Safety Manager at Ocean Mist Farms

i. Invitation sent to Mr. A.G. Kawamura

ii. Dr. Noel and Dr. Choudhury contacted for panelist recommendations

iii. Campus Catering to provide light appetizers

iv. Bottles of Cal Poly wine to serve as panelist thank you gifts

v. Brock Center Associates responsible for press releases and community outreach

3. Winter Issue of Ag Circle Magazine

a. The Brock Associates set specific due dates for various stages of magazine production and delegated the writing assignments to a large group of student writers.

b. Ellen Cohune aided the Brock Center with the editing process during Fall Quarter.

c. Agro-Culture purchased a double-page advertisement for all three issues of the Ag Circle 2012-2013. Yosemite Farm Credit, JB Dewar, AdFarm and Caroline Evangelo Communications also purchased half-page ads for the Winter issue.

d. PRP Companies was used as the printer and decreased the cost of printing with a trade in advertising on the back cover.

e. 1,500 magazines were ordered this issue in efforts to share more magazines across campus, outside of CAFES, in addition to the high schools, junior colleges with agriculture courses and county Farm Bureau offices.

f. The Winter 2012 issue was delivered on campus during the week of November 26. The BRAE Department requested 40 extra copies for their Advisory Council 
meeting.

4. Brock Website and Social Media

a. The Brock website has been transferred to Drupal and will be available early in Winter quarter.

b. Ag Circle has a Twitter account with 375 followers, an increase of 93 since Spring; the Brock Center has a Facebook page with 363 friends, an increase of 33 since Spring; and Ag Circle has a Facebook page with 941 likes, an increase of 206 since Spring.

c. The Brock Center blog on wordpress.com continues to be an outlet for students to share short stories, provide input and increase agriculture education with their words, photos and video entries. Since beginning, the blog site has over 6,000 views from its 41 posts.

5. Brock Equipment and Resource Updates

a. Megan Silcott met with Thomas Morales of the Journalism Department to learn some camera tips and tricks. He offered to work with the Brock Center more in the future.

b. A new whiteboard is being installed in the Brock Center to further accommodate the planning needs of the magazine and other projects the center has been approached with.

c. Two additional camera lenses are available for checkout along with 15 Kodak mini video cameras for student work and projects.

d. All other equipment is working well.

6. Projects

a. CAFES History Project: The videos for Russ Anderson and Dick Johnson were condensed and used at the October 6, 2012 Animal Science Reunion.

i. The Brock Center also put together the Emeriti slide show for the Reunion.

ii. Jennifer Ray and Megan Silcott met with Mr. Jim Hayes for lunch in early December. His insight and history are priceless. The conversation is recorded.

b. The California Citrus Mutual proposed a video project to go through the Brock Center by April, 2013.

c. The BRAE Department has requested a promotional video to be produced by June, 2013.

d. Dr. Vernon, Mr. Gearhart, Ellen Cohune, Dr. Kellogg and Megan Silcott met with Mary Glick, new Journalism Department Head over lunch. Discussions revolved around the history of the Brock Center, it's purpose to work hand in hand with the Journalism and Agricultural Education and Communication Departments, and building that relationship.

e. Megan Silcott presented three presentations on behalf of the Brock Center and Agricultural Education and Communication Department: New Professionals Institute, California Ag Leadership Class 43, and for the California Foundation for Agriculture in the Classroom. 


\section{Future Goals}

a. Continue updating and maintain website

b. Continue interviewing CAFES faculty legends

c. Expand the readership of Ag Circle while increasing advertising to offset printing costs

d. Develop a photo workshop with alumni support to offer students

e. Utilize the Journalism Department for broadcasting experience

Respectfully submitted, Megan A. Silcott

Megan Silcott

Brock Center Director

msilcott@calpoly.edu

805.756.2892 


\section{Winter Quarter 2013 Report}

Date: April 21, 2013

To: Dr. David Wehner, Dean CAFES

Dr. Bill Kellogg, Department Head

From: Megan Silcott, Director

Jennifer Ray, Mandy Brazil, Amanda Meneses and Taylor Pires, Brock Center

Associates

We are pleased to provide you this quarterly report reflecting Brock Center activities.

1. Open House Magazine

a. Maureen O’Conner, Jennifer Ray, Megan Silcott and Dr. Cavaletto met to review the improvements, changes, needs and content of the Open House magazine for April 2013.

b. Two meetings took place to discuss the layout and advertisements needed using spreadsheets to show the combination of businesses and Cal Poly ads to cover the printing expense.

c. PRP Companies delivered the magazines April 9 to the Dean's office.

2. 2013 Community Forum

a. Took place Wednesday, February 27 from 6:00-8:30 p.m. in the PAC Pavilion.

b. Topic: Sustainability and Food Policy and their implications on California Agriculture

i. Panelists: April Mackie, Cal Poly alumni and Food Safety Consultant, Dino Giacomazzi, Cal Poly alumni and manager of Giacomazzi Dairy Farms, Hon. Dr. Sam Blakeslee, former State Senator

ii. Campus Catering provided light appetizers

iii. Cal Poly chocolates and jam provided for panelist thank you gifts

iv. Brock Center Associates press releases ensured KSBY News covered the event for the 11:00 p.m. and 6:00 a.m. news segments. Several online community calendars posted the event.

v. About 65 students, community members and faculty attended.

3. Spring Issue of Ag Circle Magazine

a. The Brock Associates set specific due dates for various stages of magazine production and delegated the writing assignments to a large group of student writers.

b. Agro-Culture purchased a double-page advertisement for all three issues of the Ag Circle 2012-2013. Yosemite Farm Credit and Mission Avocados purchased half-page ads for the Winter issue. E.\&J. Gallo Winery purchased the inside back cover.

c. PRP Companies printed the magazine with a trade for the back cover ad.

d. 1,500 magazines are shared across campus and outside of CAFES, in addition to the 350 high schools and junior colleges with agriculture courses and 53 county Farm Bureau offices. 
e. Brock has the best problem we could ask for...too many interested student writers to fill the pages.

4. Brock Website and Social Media

a. The Brock website has been transferred to Drupal and made available early April 10, 2013.

b. Ag Circle has a Twitter account with 415 followers, an increase of 40 since Fall Quarter, the Brock Center has a Facebook page with 358 likes, a decrease of five since Fall, and Ag Circle has a Facebook page with 994 likes, an increase of 53 since Fall.

c. The Brock Center blog: brockcenter.wordpress.com continues to be an outlet for students to share short stories, provide input and increase agriculture education with their words, photos and video entries.

d. Since beginning, the blog site has had over 8,169 views from its 50 posts.

5. Brock Equipment and Resource Updates

a. A new whiteboard is now in the Brock Center to plan out writers, stories and editor-mentor assignments so deadlines are met with quality content and photos.

b. The main MAC computer has 4GM of additional RAM added to it for memory and speed.

c. An oak magazine stand is now outside the Brock Center to encourage passersby to pick up the various magazines and agriculture communication materials the center produces.

6. Projects

a. A Photoshop workshop is in planning stages. The workshop will provide a few hours of instruction and application for those interested in learning the program. Date TBD.

b. The California Citrus Mutual video project to go through the Brock Center by June, 2013. Aimee Brooks and Susana Lamb are coordinating this project with a \$3,000 donation from CCM to the Brock Center.

c. Dean Wehner, Dr. Vernon, Mr. Gearhart, Ellen Cohune, David Gillette, Beth Brenner, Mark Glick and Megan Silcott met with President Jeffrey D. Armstrong to review a potential RFD-TV project. Future meetings will occur to continue the project efforts.

7. Future Goals

a. Align more closely with the Brock Center mission and bylaws.

b. Continue updating and maintain website.

c. Utilize the Journalism Department for cross-campus projects.

d. Promote marketing services for the agriculture industry such as surveys, interviews, brochures, logo design and social media.

e. Pursue the possibility of offering a seminar/speaker series for industry professionals. 


\section{Spring Quarter 2013 Report}

Date: June 17, 2013

To: Dr. David Wehner, Dean CAFES

Dr. Doug Epperson, Dean CLA

Dr. Andy Thulin, Interim Dean CAFES

Dr. Bill Kellogg, Agricultural Education \& Communication Department Head

Professor Mary Glick, Journalism Department Head

From: Megan Silcott, Director

Jennifer Ray, Mandy Brazil, Amanda Meneses and Taylor Pires, Brock Center Associates

We are pleased to provide you this report reflecting Brock Center activities for Spring quarter.

1. Open House Magazine

a. Jennifer Ray and Dr. Cavaletto met to review the improvements, changes, needs and content of the Open House magazine for April 2013.

b. Maureen O'Connor suggested the Open House Magazine Committee be responsible for seeking, tracking, invoicing and collecting advertising funds next year.

2. Summer/Fall Issue of Ag Circle Magazine

a. The Brock Associates set specific due dates for various stages of magazine production and delegated the writing assignments to a large group of student writers.

b. Agro-Culture purchased a double-page advertisement for all three issues of the Ag Circle 2012-2013. Yosemite Farm Credit and Mission Avocados purchased half-page ads for the Summer/Fall issue.

c. PRP Companies printed the magazine with a trade for the back cover ad.

d. 1,500 magazines were shared across campus, mailed to 350 high schools and junior colleges with agriculture courses and to 53 county Farm Bureau offices.

e. Brock has the best problem we could ask for...too many interested student writers to fill the pages.

3. Brock Website and Social Media

a. The Brock website has been transferred to Drupal and made available early April 10, 2013.

b. Ag Circle has a Twitter account with 420 followers, an increase of five since April. The Brock Center has a Facebook page with 360 likes, an increase of two since April. The Ag Circle has a Facebook page with 1,013 likes, an increase of 19 since April.

c. The Brock Center blog: brockcenter.wordpress.com continues to be an outlet for students to share short stories, provide input and increase agriculture education with their words, photos and video entries.

d. Since beginning, the blog site has had over 9,508 views generated from its 56 posts. 
4. Brock Equipment and Resource Updates

a. A new 60D Canon EOS Digital Rebel camera is available for checkout at the Brock Center. The kit was purchased from Costco.

b. The oak magazine stand purchased in April has proven to be a good outlet for sharing magazines and agricultural communication information.

5. Projects

a. Taylor Pires, Jennifer Ray and Megan Silcott presented a workshop for the Morro Bay FFA Leadership Class. The workshop covered how to write press releases and get the chapter into local news channels.

b. The Upper Salinas-Las Tablas Resource Conservation District enlisted the Brock Center to help them develop and submit a 30-second and two-minute public service announcement. The announcements were completed, and submitted to El Dorado Broadcasting.

c. A Photoshop workshop is in planning stages for Fall quarter. The workshop will provide a few hours of instruction, and application for those interested in learning the program. Date TBD.

d. The California Citrus Mutual video project went through production and editing stages during Spring quarter. Aimee Brooks and Susana Lamb coordinated this project with a \$3,000 donation from CCM to the Brock Center.

e. Dean Wehner, Dean Epperson, Professor Mary Glick, Dr. Bill Kellogg, Jennifer Ray and Megan Silcott met in two sessions to discuss reestablishing the Brock Center Advisory Board. Dr. Kellogg has reached out to the Journalism Department to nominate members.

6. Future Goals

a. Align more closely with the Brock Center mission and bylaws.

b. Continue updating and maintain website.

c. Utilize the Journalism Department for cross-campus projects.

d. Promote marketing services for the agriculture industry such as surveys, interviews, brochures, logo design and social media.

e. Pursue the possibility of offering a seminar/speaker series for industry professionals.

Respectfully submitted, Megan A. Silcott

Megan Silcott

Brock Center Director

msilcott@calpoly.edu

805.756.2892 
Brock Center Director and Staff History

\begin{tabular}{|l|l|l|}
\hline Director Name & Department & Year \\
\hline Mr. Jim Hayes & Journalism & $1987-1989$ \\
\hline Dr. J. Scott Vernon & $\begin{array}{l}\text { Agricultural Education and } \\
\text { Communication }\end{array}$ & $1990-2000$ \\
\hline Richard Gearhart & $\begin{array}{l}\text { Agricultural Education and } \\
\text { Communication }\end{array}$ & $2007,2008,2009,2010$ \\
\hline Megan Silcott & $\begin{array}{l}\text { Agricultural Education and } \\
\text { Communication }\end{array}$ & $2011,2012,2013$ \\
\hline
\end{tabular}

\begin{tabular}{|l|l|l|}
\hline Brock Center Associate Names & Year & Additional Year(s) \\
\hline Anna (Newlander) Negranti & 1978 & 1979 \\
\hline Sheryl Athenour Flores & 1978 & \\
\hline Missy (Arnold) Hansen & 1978 & 1979 \\
\hline Bill Schlotter & 1979 & \\
\hline Abbie Dutcher & 1979 & \\
\hline Carolyn Goulding & 1979 & \\
\hline Judy White & 1979 & \\
\hline Barbara Criswell & 1979 & \\
\hline Anna Cekola & 1986 & \\
\hline Brian Albertoni & 1986 & 1987 \\
\hline Kim Gimenez & 1986 & \\
\hline Natalie Bettencourt & 1986 & 1987 \\
\hline Sandy Bradley & 1986 & \\
\hline Cindi Floyd & 1987 & 1988 \\
\hline Sam Chuck & 1987 & \\
\hline Wade Meneses & 1987 & 1988 \\
\hline Stephanie Dias & 1988 & 1989 \\
\hline Jenny (Midtgaard) Derry & 1989 & 1990 \\
\hline Rob Brockmeyer & 1990 & 1991 \\
\hline Meredith (Rehrman) Ritchie & 1991 & 1992 \\
\hline Liz Magill & 1992 & 1993 \\
\hline Sabrina Allen & 1992 & 1993 \\
\hline Jennifer West & 1993 & $1994,1995,1996$ \\
\hline Keri (Greenberg) Frank & 1993 & 1994,1995 \\
\hline Chloe Hunt & 1993 & \\
\hline Marytina Marshall & 1994 & \\
\hline & & \\
\hline
\end{tabular}




\begin{tabular}{|l|l|l|}
\hline Brock Center Associate Names & Year & Additional Year(s) \\
\hline Celeste Jones & 1994 & \\
\hline Carl Tenter & 1995 & \\
\hline Rachel Colacchia & 1996 & 1997 \\
\hline Colleen Walsh & 1997 & 1999,1998 \\
\hline Jennifer Nilsen & 1997 & 2000 \\
\hline Ashley McLaughlin & 1997 & \\
\hline Andrea Quinn & 1998 & \\
\hline Tiffany (Rausser) Moffatt & 1998 & \\
\hline Beverly Dodson & 1999 & \\
\hline Elizabeth (Ritter) Gianini & 1999 & \\
\hline Nick Garcia & 2000 & 2002 \\
\hline Sharlene (Swaim) Garcia & 2000 & 2003 \\
\hline Tobie Head & 2000 & \\
\hline Brandy Alvera & 2003 & 2004 \\
\hline Jonnalee Henderson & 2003 & 2004,2005 \\
\hline Beth (Sequeira) Souza & 2005 & 2006 \\
\hline Lindsey Liebig & 2005 & \\
\hline Megan (Sodersom) Richey & 2005 & \\
\hline Liza Teixeira & 2006 & 2007,2008 \\
\hline Jenny Konschak & 2007 & 2006 \\
\hline Alexis (White) Negranti & 2008 & 2009 \\
\hline Mindy (Burris) Derohan & 2008 & 2009,2010 \\
\hline Jiana Escobar & 2009 & 2010,2011 \\
\hline Anthony Pannone & 2010 & 2011 \\
\hline David Jones & 2010 & 2011,2012 \\
\hline Carrie Isaacson & 2011 & 2012 \\
\hline Daniel Coultas & 2011 & \\
\hline Jennifer Ray & 2011 & 2012,2013 \\
\hline Lesie Friend & 2011 & 2012 \\
\hline Amanda Meneses & 2012 & 2013 \\
\hline Mandy Brasil & 2012 & 2013 \\
\hline Taylor Pires & 2012 & 2013 \\
\hline Jordan Dunn & 2013 & 2014 \\
\hline Kenna Lewis & 2013 & 2014 \\
\hline Harrison Reilly & 2014 & \\
\hline Kathryn Roberti & 2014 & \\
\hline & & \\
\hline
\end{tabular}

